\title{
Mapping Global Forest Aboveground Biomass with Spaceborne LiDAR, Optical Imagery, and Forest Inventory Data
}

\author{
Tianyu Hu ${ }^{1, \dagger}$, Yanjun Su ${ }^{1,2, \dagger}$, Baolin Xue ${ }^{1}$, Jin Liu ${ }^{1}$, Xiaoqian Zhao ${ }^{1}$, Jingyun Fang ${ }^{1,3}$ \\ and Qinghua Guo ${ }^{1,2, *}$ \\ 1 State Key Laboratory of Vegetation and Environmental Change, Institute of Botany, \\ Chinese Academy of Sciences, Beijing 100093, China; safarihu@gmail.com (T.H.); \\ suyanjun1987@gmail.com (Y.S.); xuebaolin@ibcas.ac.cn (B.X.); liujing1030@ibcas.ac.cn (J.L.); \\ zhaoxiaoqian@ibcas.ac.cn (X.Z.); jyfang@urban.pku.edu.cn (J.F.) \\ 2 Sierra Nevada Research Institute, School of Engineering, University of California at Merced, \\ Merced, CA 95343, USA \\ 3 Department of Ecology, College of Urban and Environmental Sciences, and Key Laboratory for Earth Surface \\ Processes of the Ministry of Education, Peking University, Beijing 100871, China \\ * Correspondence: guo.qinghua@gmail.com; Tel.: +1-209-228-2911 \\ + These authors contributed equally to this work.
}

Academic Editors: Nicolas Baghdadi and Prasad S. Thenkabail

Received: 28 February 2016; Accepted: 30 June 2016; Published: 4 July 2016

\begin{abstract}
As a large carbon pool, global forest ecosystems are a critical component of the global carbon cycle. Accurate estimations of global forest aboveground biomass (AGB) can improve the understanding of global carbon dynamics and help to quantify anthropogenic carbon emissions. Light detection and ranging (LiDAR) techniques have been proven that can accurately capture both horizontal and vertical forest structures and increase the accuracy of forest AGB estimation. In this study, we mapped the global forest AGB density at a 1-km resolution through the integration of ground inventory data, optical imagery, Geoscience Laser Altimeter System/Ice, Cloud, and Land Elevation Satellite data, climate surfaces, and topographic data. Over 4000 ground inventory records were collected from published literatures to train the forest AGB estimation model and validate the resulting global forest AGB product. Our wall-to-wall global forest AGB map showed that the global forest AGB density was $210.09 \mathrm{Mg} / \mathrm{ha}$ on average, with a standard deviation of $109.31 \mathrm{Mg} / \mathrm{ha}$. At the continental level, Africa (333.34 $\pm 63.80 \mathrm{Mg} / \mathrm{ha})$ and South America (301.68 $\pm 67.43 \mathrm{Mg} / \mathrm{ha}$ ) had higher AGB density. The AGB density in Asia, North America and Europe were $172.28 \pm 94.75,166.48 \pm 84.97$, and $132.97 \pm 50.70 \mathrm{Mg} / \mathrm{ha}$, respectively. The wall-to-wall forest AGB map was evaluated at plot level using independent plot measurements. The adjusted coefficient of determination $\left(R^{2}\right)$ and root-mean-square error (RMSE) between our predicted results and the validation plots were 0.56 and $87.53 \mathrm{Mg} / \mathrm{ha}$, respectively. At the ecological zone level, the $R^{2}$ and RMSE between our map and Intergovernmental Panel on Climate Change suggested values were 0.56 and $101.21 \mathrm{Mg} / \mathrm{ha}$, respectively. Moreover, a comprehensive comparison was also conducted between our forest AGB map and other published regional AGB products. Overall, our forest AGB map showed good agreements with these regional AGB products, but some of the regional AGB products tended to underestimate forest AGB density.
\end{abstract}

Keywords: global; forest; aboveground biomass; remote sensing; LiDAR 


\section{Introduction}

Global forest ecosystems, which cover $30 \%$ of the land surface, play an important role in the global carbon cycle since they sequester atmospheric carbon dioxide and are able to mitigate global warming [1,2]. Aboveground biomass (AGB) is the total amount of biological material (usually based on a dry weight) presented above the ground in a specified area. Since approximately $50 \%$ of plant biomass is composed of carbon, accurate estimation of the total AGB in forest ecosystems is critical for carbon cycle studies from local to global scales [3]. For example, the amount and distribution of regional to global biomass can provide either initial conditions or validations for ecosystem and biogeochemical models [4-7], which simulate the exchange of carbon and energy between the atmosphere and biosphere. They can also provide the baseline of forest carbon stocks for calculating carbon fluxes from deforestation, land cover change, and other disturbances $[8,9]$. Moreover, biomass and its change also act as indicators of other ecosystem services, such as biodiversity [10]. Consequently, accurate estimations of the regional to global distribution of forest AGB are of great benefit to improve our understanding of carbon dynamics and quantify anthropogenic emissions caused by deforestation and forest degradation against the background of global climate change [11-13].

Generally, forest inventories are recognized as the most accurate method for providing information on biomass at local or regional scales [14,15]. However, these approaches are usually time-consuming and labor-intensive when applied to large areas, and also cannot provide spatially continuous AGB measurements [16]. Compared with traditional forest inventory methods, the availability of remote sensing techniques has greatly improved the efficiency and lowered the cost of forest AGB mapping, especially in remote areas $[17,18]$. Remote sensing techniques cannot directly acquire forest AGB measurements. Instead, they are used with regression models, which are built by linking ground measurements with remotely sensed data.

Currently, passive optical remote sensing, radar, and light detection and ranging (LiDAR) techniques are the three commonly used remotely sensed data sources for mapping forest AGB. Among these three techniques, passive optical remote sensing (e.g., Landsat Thematic Mapper data and MODIS (Moderate Resolution Imaging Spectroradiometer) data) and radar (e.g., phased array L-band Synthetic Aperture Radar (SAR)) are the more frequently used data sources because of their availability at regional to global scales [19-21]. However, many studies have demonstrated that approaches using optical remotely sensed data are limited by the saturation effect of optical sensors, and the saturation points can range from 15 to $150 \mathrm{Mg} /$ ha depending on different sensors [22-30]. The saturation points for active SAR are higher than for optical sensors (ranging from 30 to over $300 \mathrm{Mg} /$ ha based on the use of different frequencies and polarization methods), because SAR is more sensitive to forest spatial structures and standing biomass [31-35].

LiDAR, as an alternative active remote sensing technique, uses a focused short-wavelength laser pulse, which can penetrate the forest canopy more effectively [36]. With its ability to detect the vertical structures in forests, LiDAR has proved to be an efficient tool in the study of forest AGB estimation in a variety of forest environments [37-41]. Currently, the saturation phenomenon is rarely observed in the LiDAR approach, even in forests with high AGB levels; and the accuracy of forest AGB mapping can be significantly improved by using LiDAR, compared with optical passive and radar approaches $[39,42,43]$. However, LiDAR currently has disadvantages in temporal and spatial coverages, which has limited its application in global forest AGB estimation. Neither of the two major LiDAR platforms, airborne LiDAR and spaceborne LiDAR, can provide globally continuous LiDAR measurements. So far, airborne LiDAR data are only available in certain small areas because of the relatively high cost of airborne LiDAR flight missions $[44,45]$. The only available spaceborne LiDAR system, Geoscience Laser Altimeter System (GLAS) onboard the Ice, Cloud, and Land Elevation Satellite (ICESat), can provide worldwide LiDAR data. However, the density of the GLAS footprint is too low to directly produce a wall-to-wall forest AGB map [46].

Recently, many studies have tried to integrate multisource data to overcome the deficiencies of GLAS data and estimate regional- to continental-scale forest AGB. One of the major problems in these 
studies is how to build correlations between plot measurements and GLAS footprints considering the relatively low density of GLAS footprints. Generally, there are three ways to link forest inventories data and GLAS points [47]. (1) Direct links based on the geolocation [48-50]. Baccini et al. [49] used field data that were collected within the GLAS footprints to calibrate GLAS observations, and then used GLAS observations and other remote sensing data to generate a spatially continuous AGB in a pan-tropical forest; (2) The use of airborne LiDAR data as a medium [38]. Boudreau et al. [38] first used airborne LiDAR data to calibrate GLAS observations in parts of the study area, and then extrapolated GLAS observations using other remote sensing data to the whole study area in Québec, Canada; (3) Extrapolation of GLAS parameters [47,51]. Instead of linking ground measurements with GLAS data at the footprint level, Su et al. [47] first extracted GLAS full-waveform parameters and used statistical methods to extrapolate them into spatially continuous layers. Then, they used these extrapolated layers as predictors to build statistical models based on ground inventories, and estimated continuous forest AGB distribution in China. No matter which method is chosen, having a sufficient number of ground measurements that are well distributed across the world is a pre-requisite to estimate the distribution of global-scale forest AGB.

Although biomass maps based on multisource remote sensing data have recently become available in certain national [47,52], pan-tropical [48,49], circumboreal [53], and northern boreal and temperate forests [54], spatially explicit datasets on global forest AGB in a single product have been rarely seen up to now. In this study, our objective was to estimate global forest AGB using a combination of ground inventory data, spaceborne LiDAR, optical imagery, climate surfaces, and topographic data. Over 4000 plot measurements were collected from published literature to address this objective. This study selected extrapolation of GLAS parameters (the third method mentioned above) as the method to map global forest AGB [47] because there was only a low chance that the collected plot measurements would coincide with the GLAS footprints and sufficient airborne LiDAR data were not available. The resulting global wall-to-wall forest AGB map at 1-km resolution can be downloaded from web [55]. This new product can help to improve the accuracy of predictions of carbon dynamics and quantify the carbon fluxes from deforestation, land cover change, and other disturbances.

\section{Materials and Methodology}

As mentioned, this study chose the framework developed by Su et al. [47], which has been successfully used to estimate the nationwide forest AGB of China, to estimate global forest AGB. In line with the framework (Figure 1), we collected forest ground inventory, GLAS, Normalized Difference Vegetation Index (NDVI), topographic, climatic and land cover data (Table 1). Detailed descriptions of each dataset and a brief introduction to the AGB estimation methodology are given below.

Table 1. Variables used in the random forest method to model aboveground biomass of forests.

\begin{tabular}{|c|c|c|c|c|}
\hline Variable & Dataset & Year & Resolution & Reference \\
\hline Annual Mean Precipitation (mm) & Worldclim & 1950-2000 & $1 \mathrm{~km}$ & Hijmans et al., 2005 [56] \\
\hline $\begin{array}{l}\text { Precipitation Seasonality } \\
\text { (Coefficient of Variation) }\end{array}$ & Worldclim & 1950-2000 & $1 \mathrm{~km}$ & Hijmans et al., 2005 [56] \\
\hline Annual Mean Temperature $\left({ }^{\circ} \mathrm{C}\right)$ & Worldclim & 1950-2000 & $1 \mathrm{~km}$ & Hijmans et al., 2005 [56] \\
\hline $\begin{array}{l}\text { Temperature Seasonality } \\
(\text { standard deviation } \times 100)\end{array}$ & Worldclim & 1950-2000 & $1 \mathrm{~km}$ & Hijmans et al., 2005 [56] \\
\hline Elevation (m) & SRTM & 2000 & $1 \mathrm{~km}$ & Jarvis et al., 2008 [57] \\
\hline Slope & SRTM & 2000 & $1 \mathrm{~km}$ & \\
\hline NDVI & MOD13A2 & 2004 & $1 \mathrm{~km}$ & [58] \\
\hline Land Cover & MCD12Q1 & 2004 & $1 \mathrm{~km}$ & {$[59,60]$} \\
\hline Waveform Extent & GLAS & 2004 & & \\
\hline Leading Edge Extent & GLAS & 2004 & & \\
\hline Trailing Edge Extent & GLAS & 2004 & & \\
\hline
\end{tabular}




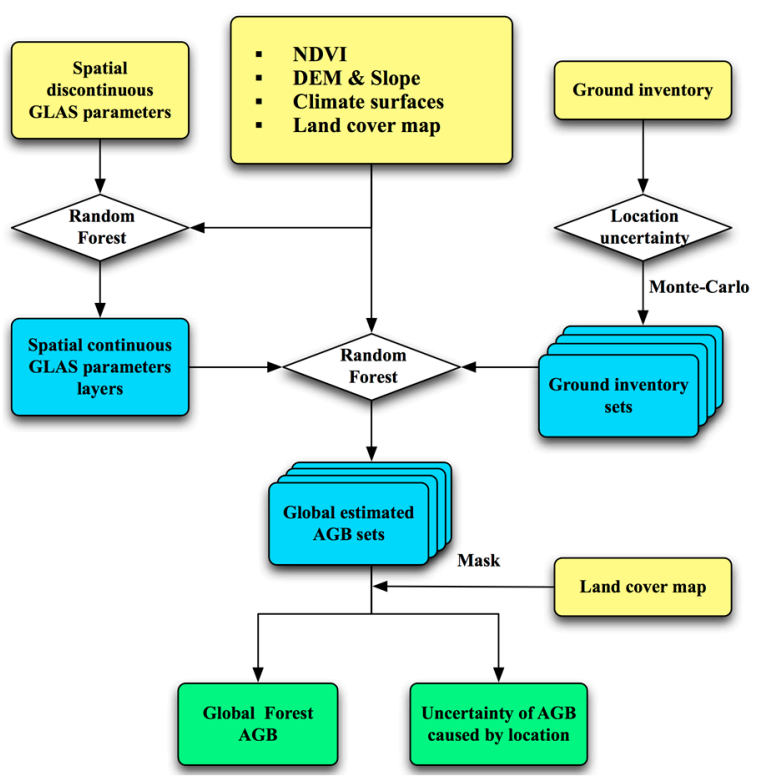

Figure 1. The workflow for estimating global forest aboveground biomass (AGB) distribution from multisource remotely sensed data and ground inventory data.

\subsection{Ground AGB Measurements}

A sufficient amount of ground inventory data is fundamental to estimate forest AGB from remotely sensed data, no matter which methods are chosen. In this study, we collected 4090 records of plot measurements from papers published between 1990 and 2013. The allometric equations used in these literatures were based on either DBH (diameter at breast height) or DBH and tree height (Table S1). Some literatures directly provided the carbon density $(\mathrm{Mg} \cdot \mathrm{C} / \mathrm{ha}$ ) and we used a common factor of 2.0 to convert the carbon density to biomass density (Mg/ha) [14]. The stand origin (plantation or natural forest), plot size, measurement method, data publication year, and AGB value for each individual record are provided in the supplementary materials. To ensure the in-situ plot measurements were representative to the forest conditions of corresponding locations, the collected plot measurements were further filtered to ensure they were larger than 0.05 ha in size. The records measured through harvesting methods were also excluded from the AGB estimation procedures. In total, 3348 plot samples were retained in this study for the forest AGB mapping procedure (Figure 2; Table S2).

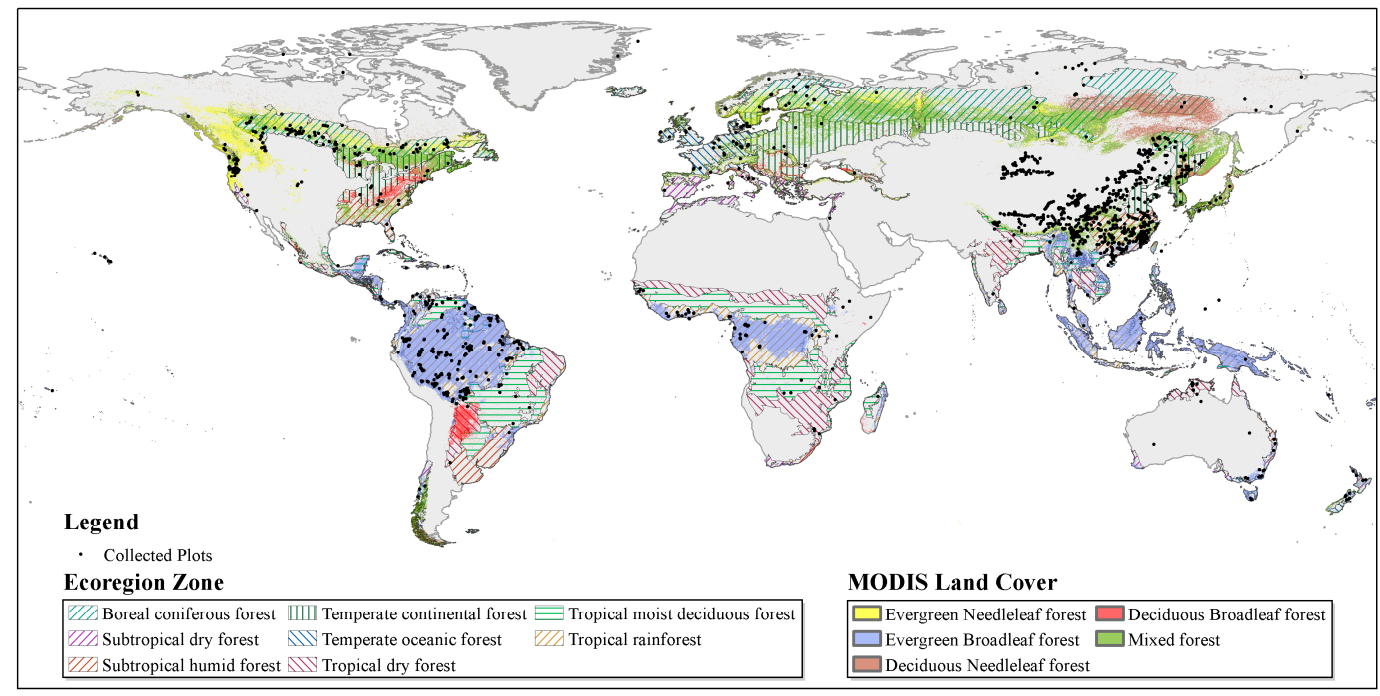

Figure 2. Geolocations of the collected ground inventory data. The background maps are the ecoregion zone map and land cover map from MODIS 2004. 


\subsection{GLAS Data}

The GLAS instrument was onboard the NASA (National Aeronautics and Space Administration) ICESat satellite, which was launched on 12 January 2003. It was equipped with three laser sensors, L1-L3, each of which has a 1064-nm laser channel for surface altimetry and dense cloud heights. The ellipsoidal footprints of $\sim 65 \mathrm{~m}$ in diameter were spaced at $170 \mathrm{~m}$ along the track and at tens of kilometers across tracks [61]. In this study, we selected GLAS data from the operating periods L2B, L2C, and L3A (17 February 2004 to 9 November 2004) for the AGB mapping procedure. Three GLAS products, namely GLA01, GLA06, and GLA14, were downloaded from the ICESat/GLAS data pool. They respectively recorded the full-waveform, geolocation and data quality, and surface elevation information of each laser shot. These three products were linked by the combination of a unique record index (i_rec_ndx) and shot count (i_shot_count) for each shot.

To ensure the quality of the GLAS measurements, we further applied four criteria to filter the GLAS laser shots, namely: (1) should be cloud free (FRir_qa_flg = 15); (2) should have no saturation effects (i_sat Ndx<2); (3) should have high signal to noise ratios (i.e., >50); and (4) should not be significantly higher (i.e., $<100 \mathrm{~m}$ ) than the land surface elevation denoted by the Shuttle Radar Topography Mission (SRTM) data. Finally, 4,513,563 full-waveform records were retained in the final GLAS dataset. Working from the definitions of the waveform extent, leading edge extent, and trailing edge extent [62], we derived these three parameters from the full-waveform information of each laser shot. These variables have been shown to be highly correlated with canopy height, canopy height variability, and terrain slope, respectively [38,62-64].

\subsection{NDVI Data}

We selected MODIS-Terra MOD13A2 data as the source of NDVI data [58]. These data are computed from atmospherically corrected MODIS bi-directional surface reflectance data that have been masked for water, clouds, heavy aerosols, and cloud shadows. MOD13A2 data are provided every 16 days at $1-\mathrm{km}$ spatial resolution in the sinusoidal projection. In this study, we collected global MOD13A2 data during 2004 from the Land Processes Distributed Active Archive Center (LP DAAC) data pool. Since cumulative NDVI from a time-series can increase the AGB estimation accuracy compared with the use of NDVI data from a single time period [45], we computed the cumulative NDVI from the sum of all NDVI data in the growing season of 2004 and used this as a predictor in forest AGB estimations.

\subsection{Topographic Data}

The elevation and slope were two important factors in the forest AGB mapping procedures proposed by Su et al. (2016) [47]. In this study, we chose the SRTM digital elevation model (DEM) data to obtain land surface elevation and slope information, which covers $99.97 \%$ of the Earth land surface from $56^{\circ} \mathrm{S}$ to $60^{\circ} \mathrm{N}[65,66]$. We downloaded the 4.1 version of the SRTM data at a resolution of $90 \mathrm{~m}$ from the Consultative Group for International Agricultural Research-Consortium for Spatial Information (CGIAR-CSI) [57]. For consistency with other datasets, the SRTM DEM was resampled to $1-\mathrm{km}$ resolution for further steps, and the slope product was derived from the resampled SRTM DEM.

\subsection{Climatic Data}

Climate conditions have a profound impact on the potential forest AGB $[67,68]$. We collected four bioclimatic variables between 1950 and 2000 from the WorldClim dataset, namely annual mean temperature, annual temperature seasonality, annual total precipitation, and annual precipitation seasonality [56]. These climate surfaces were provided in 1-km grids.

\subsection{Land Cover Data}

The global mosaics of the standard MODIS land cover type data product (MCD12Q1) in the IGBP Land Cover Type Classification was used in this study [59,60]. MCD12Q1 has provided an annual land 
cover map since 2001. For consistency with GLAS data, we downloaded a land cover map for 2004 from the Global Land Cover Facility.

\subsection{Forest AGB Estimation Methods}

As mentioned, this study used the AGB estimation framework developed by Su et al. (2016) [47] to estimate the global forest AGB. Detailed descriptions of the framework can be found in Su et al. (2016) [47]. As shown in Figure 1, the framework can generally be divided into four major steps.

First, the three discrete GLAS full-waveform parameters were extrapolated into spatial continuous layers using the random forest (RF) algorithm. Each of the three parameters were first aggregated into $1-\mathrm{km}$ pixels using the average value of the corresponding parameter within each pixel. These 1-km pixels were used as training data to build the RF models to extrapolate the GLAS parameters based on prediction variables (i.e., cumulative NDVI, DEM, slope, climate surfaces, and land cover map).

Second, 100 sets of ground plot measurements with plot location uncertainty were generated. Most geolocations for the collected plots were accurate to $0.01^{\circ}$ (corresponding to $\sim 1 \mathrm{~km}$ ), but some were only accurate to $0.1^{\circ}$ (corresponding to $\sim 10 \mathrm{~km}$ ). As suggested by Su et al. (2016) [47], the plot location uncertainty may be too large and bring unneglectable error when linking the plots with other prediction variables. To minimize the influence of the plot location uncertainty on the forest AGB estimation, Su et al. (2016) [47] introduced an uncertainty field model into the forest AGB mapping procedure. This method assumed that the real plot center is randomly located within a circular buffer zone of the provided plot location. The radius of the buffer is determined by the uncertainty of the plot location ( $1 \mathrm{~km}$ or $10 \mathrm{~km}$ in this study). Then, a large number of plot measurements sets (i.e., 100 in this study) were randomly generated within these buffers using Monte-Carlo simulation.

Third, the initial global forest AGB distribution was mapped. Each set of the plot measurements with location uncertainty from the previous step was used as training data to estimate one global forest AGB distribution layer. The RF algorithm was used to build the regression models, and the three extrapolated GLAS parameters along with the eight parameters in Table 1 were used as explanatory variables. The initial global forest AGB map was computed as the average of the results from these 100 separate runs.

Finally, non-forested areas were masked to refine the forest AGB map. The initial global forest AGB map was further masked by the land cover map. The final global forest AGB map was obtained by setting the forest AGB density in areas without forest coverage as $0 \mathrm{Mg} / \mathrm{ha}$.

The RF method for extrapolating the GLAS parameters and estimating forest AGB distribution was implemented using the randomForest $R$ package [69]. The land cover map was used as a dummy variable in the RF regression procedures. Each land cover type was represented by a unique numerical identification number and fed into the RF regression tree models. Not all of the retained 3348 plots were used in the procedure of mapping global forest AGB distribution. Approximately $70 \%$ of the plots were randomly used to map the forest AGB and the other 30\% were used to evaluate the forest AGB estimation result.

\subsection{Accuracy Assessment}

In this study, we used the adjusted coefficient of determination $\left(R^{2}\right)$ and root-mean-square error (RMSE) to evaluate the accuracy of the estimated global forest AGB at the plot level. The plot-level accuracy was assessed by directly comparing the estimated result with the independent validation ground inventory dataset. Moreover, the ecoregion-level AGB value was compared with the IPCC suggested value in each ecoregion.

We further conducted a comprehensive comparison between our estimated result and other published regional forest AGB products at the pixel level. Table 2 shows the regional forest AGB products that were used to make the comparison. As can be seen, most currently available published forest AGB products are concentrated in three regions, pan-tropical areas, boreal forest, and the continental U.S. The spatial similarity between our product and these other regional products was 
compared in two ways: direct pixel-level differencing and the use of the Fuzzy Numerical (FN) index map. The FN index map can measure the similarity of spatial patterns between two numerical raster maps at the pixel level [70,71]. The FN index, ranging between 0 (fully distinct maps) and 100 (fully identical maps), can be computed as the average of the numerical similarity $s$ between each pair of corresponding cells ( $a$ and $b$ ) in two maps, which in turn can be computed cell-by-cell as follows:

$$
s(a, b)=\left(1-\frac{|a-b|}{\max (|a|,|b|)}\right) \times 100
$$

where the cell values ( $a$ and $b$ ) are re-computed considering the neighboring cells within a specified window, such as $1 \times 1$ (in this study), $3 \times 3,5 \times 5$.

Table 2. Main characteristics of the AGB maps used for the comparison in this study.

\begin{tabular}{ccccc}
\hline AGB Map & Coverage & Year & Resolution & Reference \\
\hline Saatchi map & Pan-tropic & 2000 & $1 \mathrm{~km}$ & {$[48]$} \\
Baccini map & Pan-tropic & $2007-2008$ & $500 \mathrm{~m}$ & {$[49]$} \\
Avitabile map & Pan-tropic & $\sim 2000$ & $1 \mathrm{~km}$ & {$[72]$} \\
Ruesch \& Gibbs map & Global & 2000 & $1 \mathrm{~km}$ & {$[73]$} \\
Margolis map & North America & $2005-2006$ & $1 \mathrm{~km}$ & {$[74]$} \\
Thurner map & Northern Hemisphere & 2010 & $1 \mathrm{~km}$ & {$[54]$} \\
Neigh map & Euro-Asia & $2005-2006$ & $1 \mathrm{~km}$ & {$[75]$} \\
Blackard map & U.S. & 2001 & $1 \mathrm{~km}$ & {$[76]$} \\
Saatchi map & U.S. & $\sim 2005$ & $1 \mathrm{~km}$ & {$[77]$} \\
\hline
\end{tabular}

\section{Results}

\subsection{Wall-to-Wall Global Forest AGB Map}

Figure 3 shows the distributions of the three extrapolated GLAS parameters. In general, the RF regression models explained $64.1 \%, 51.4 \%$, and $55.1 \%$ of the variances in waveform extent, leading edge extent, and trailing edge extent, respectively. The mean root-mean-square residuals for the extrapolated waveform extent, leading edge extent, and trailing edge extent were $16.08 \mathrm{~m}, 12.8 \mathrm{~m}$, and $4.7 \mathrm{~m}$, respectively. These three extrapolated GLAS parameters along with the other eight collected predictors were used to estimate the global wall-to-wall forest AGB map. The resulting global wall-to-wall forest AGB map is shown in Figure 4 and can be downloaded from the web [55]. The RF regression tree model built from plot measurements without considering plot location uncertainty explained $61.21 \%$ of the variances in forest AGB and the root-mean-squared residual was $99.30 \mathrm{Mg} / \mathrm{ha}$. The importance of each variables was provided in the Figure S1. The final global forest AGB result indicated that the mean AGB density for global forests was $210.09 \mathrm{Mg} / \mathrm{ha}$ with a standard deviation of $109.31 \mathrm{Mg} / \mathrm{ha}$.

The forest AGB density gradually increased from the boreal forest area to the tropical forest area (Figure 4a). The boreal coniferous forests, which were mainly distributed in northern Europe, northern Asia, and northern North America, had relatively low average forest AGB densities (111.63, 97.49 and $126.80 \mathrm{Mg} / \mathrm{ha}$, respectively). The internal variation of the forest AGB in these areas was also low (16, 20 and $18 \mathrm{Mg} /$ ha, respectively). The temperate continental forests, which were mainly distributed in eastern Asia, western Europe, and eastern North America, had slightly higher forest AGB densities compared with the boreal coniferous forests $(131.34,120.70$, and $155.85 \mathrm{Mg} / \mathrm{ha}$ on average, respectively). The temperate oceanic forests were mainly distributed in Eastern Europe with a few areas in western North America, southern South America, and New Zealand. The mean AGB density of temperate oceanic forest in Europe was $184.20 \mathrm{Mg} / \mathrm{ha}$, which was lower than other temperate oceanic forests (North America 317.28 Mg/ha, South America 435.45 Mg/ha, and New Zealand $527.15 \mathrm{Mg} / \mathrm{ha}$ ). The internal variations of the forest AGB in these areas were higher compared 
with the boreal areas: $80.01 \mathrm{Mg} / \mathrm{ha}$ in Europe, $109.71 \mathrm{Mg} / \mathrm{ha}$ in New Zealand, $98.47 \mathrm{Mg} / \mathrm{ha}$ in North America, and $84.56 \mathrm{Mg} / \mathrm{ha}$ in South America.

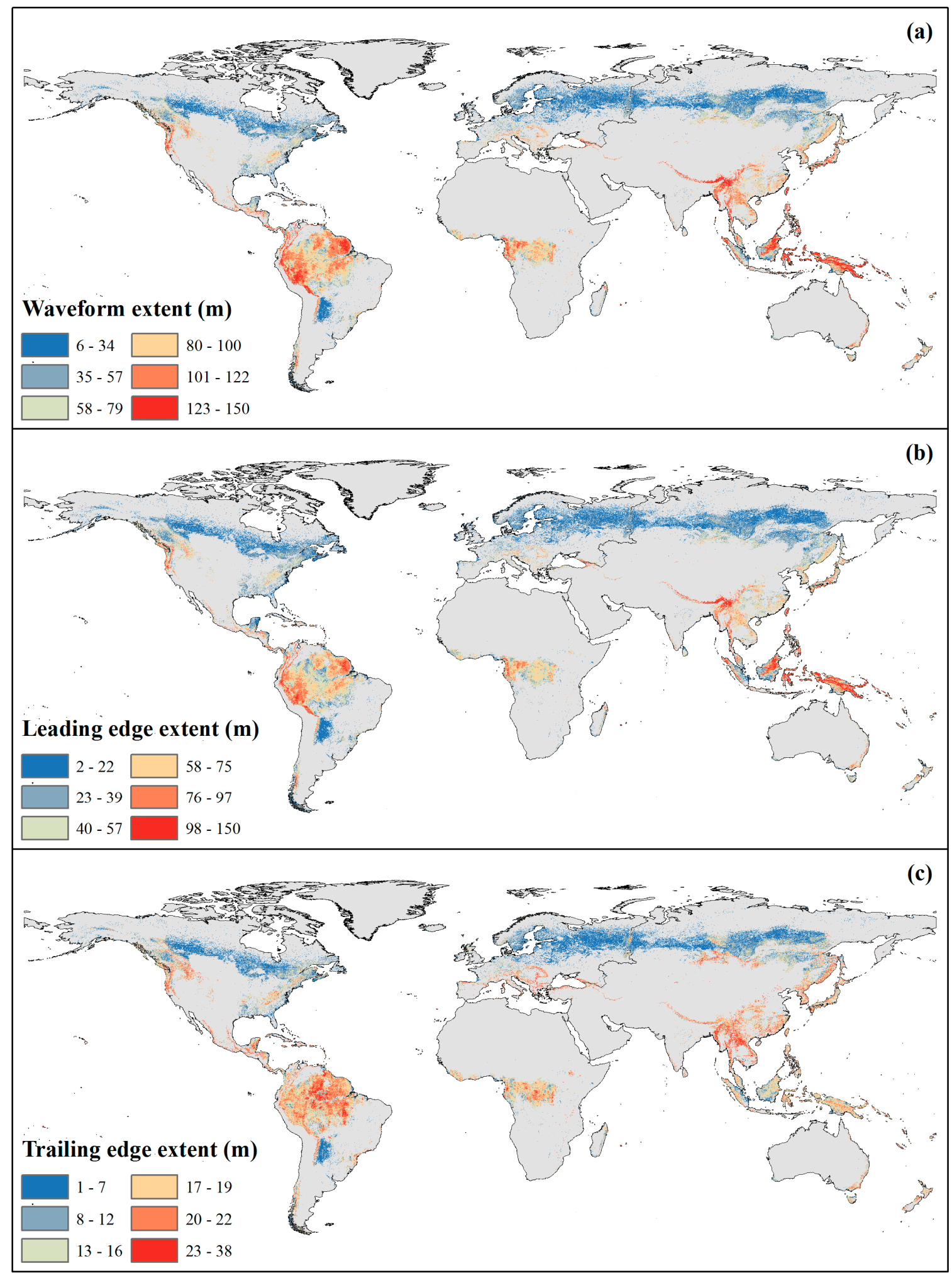

Figure 3. Distributions of extrapolated GLAS-derived full-waveform parameters, (a) waveform extent; (b) leading edge extent; and (c) trailing edge extent. Note that non-forest coverage has been excluded from the maps. 


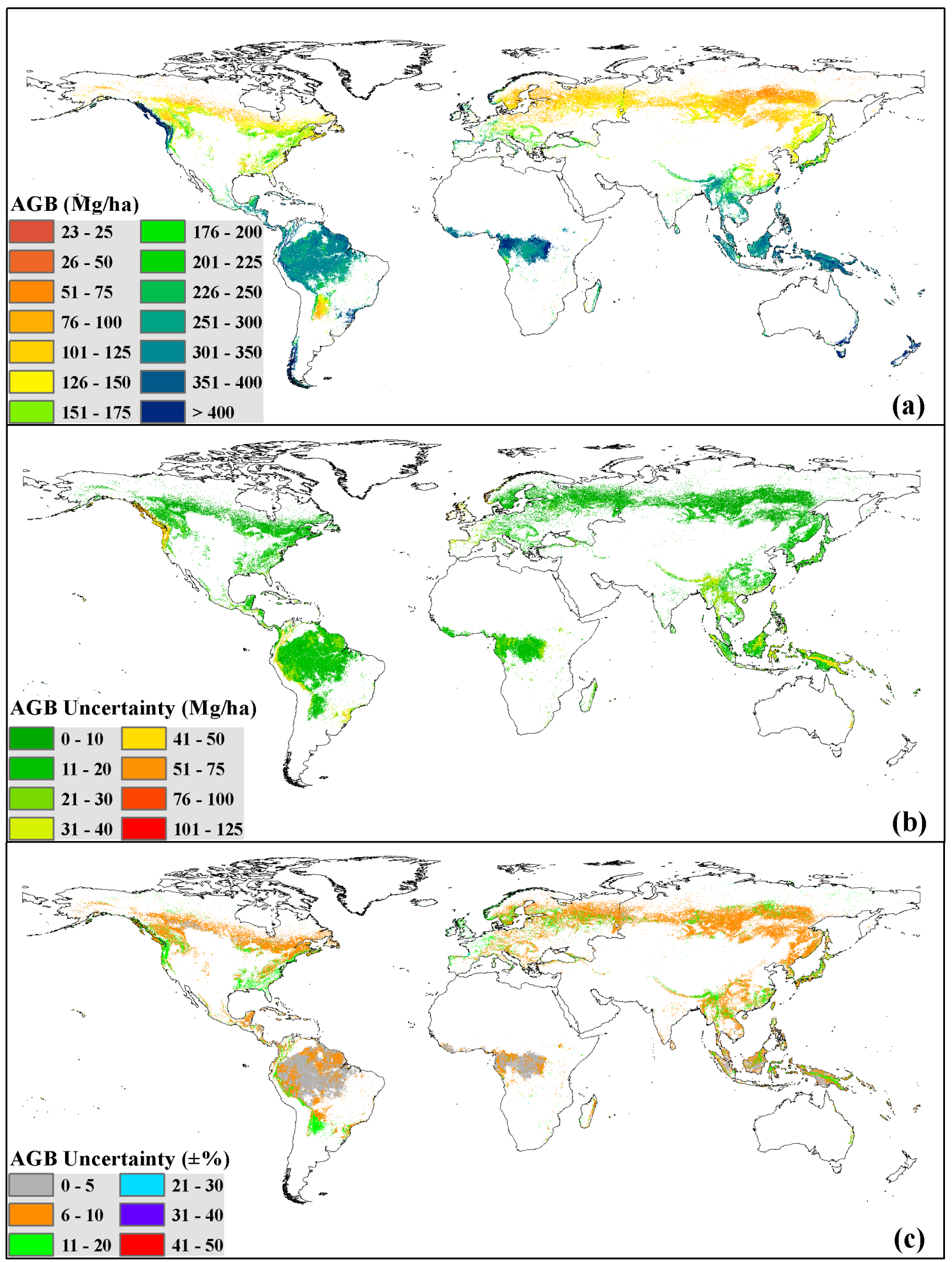

Figure 4. (a) The derived wall-to-wall map of global forest AGB in this study; (b) the absolute uncertainty induced by plot location uncertainty (estimated as the standard deviation of the $100 \mathrm{RF}$ run results); and (c) the relative uncertainty induced by plot location uncertainty. The study region was bounded at $80^{\circ}$ north latitude and $58^{\circ}$ south latitude and from longitude $-180^{\circ}$ to $180^{\circ}$.

The subtropical dry forests (Mediterranean) were mainly distributed in Southern Europe $(193.62 \pm 51.85 \mathrm{Mg} / \mathrm{ha})$ with a few areas in North America, South America (333.72 $\pm 55.95 \mathrm{Mg} / \mathrm{ha})$, Asia (157.96 $\pm 19.91 \mathrm{Mg} / \mathrm{ha})$, and Africa $(242.90 \pm 89.24 \mathrm{Mg} / \mathrm{ha})$. Subtropical humid forests were 
mainly distributed in Asia, southern North America, and South America. The subtropical humid forest in South America had the highest AGB density (336.65 Mg/ha) and variation (101.15 Mg/ha) compared with those in Asia $(171.41 \pm 53.28 \mathrm{Mg} / \mathrm{ha})$ and North America $(141.43 \pm 26.24 \mathrm{Mg} / \mathrm{ha})$. Tropical rainforests are usually known for having the highest AGB density compared with other forests. The tropical rainforests in Africa had the highest mean AGB density $(341.44 \pm 51.14 \mathrm{Mg} / \mathrm{ha})$ compared with those in South America (309.48 $\pm 30.26 \mathrm{Mg} / \mathrm{ha}$ ) and Asia (305.17 $\pm 33.42 \mathrm{Mg} / \mathrm{ha})$. Since they experienced 3-5 dry months in winter, the AGB density of tropical moist deciduous forests was lower than the tropical rainforest (Africa $240.16 \pm 73.15 \mathrm{Mg} / \mathrm{ha}$, Asia $259.15 \pm 40.57 \mathrm{Mg} / \mathrm{ha}$, and South America $258.36 \pm 72.74 \mathrm{Mg} / \mathrm{ha}$ ). Tropical dry forests had the lowest AGB density in the tropics. The tropical dry forest in South America had an AGB density of $138.93 \pm 51.26 \mathrm{Mg} / \mathrm{ha}$ compared with Africa (178.57 $\pm 65.78 \mathrm{Mg} / \mathrm{ha})$ and Asia $(226.58 \pm 59.68 \mathrm{Mg} / \mathrm{ha})$.

At the continental level, South America forests had the highest AGB stock (188.68 Pg) since the high AGB density (301.68 $\pm 67.43 \mathrm{Mg} / \mathrm{ha})$ and larger forest areas (608.6 Mha) (Table 3). The AGB stock in Asia, North America, Africa, and Europe was 143.14, 77.46, 64.65 and 40.83 Pg, respectively. Although Australia and Oceania had high average AGB density (415.66 and $424.30 \mathrm{Mg} / \mathrm{ha}$, respectively), the total AGB in Australia and Oceania was low (8.69 and $9.30 \mathrm{Pg}$, respectively) since there are relatively small forest areas. At the national level, the Brazil forests had the highest AGB stock (97.44 Pg) since the high AGB density (306.79 $\pm 36.1 \mathrm{Mg} / \mathrm{ha}$ ) and large forest areas (317.34 Mha). Russian Federation had the secondary AGB stock $(59.87 \mathrm{Pg})$ since the largest forest cover (530.48 Mha), and forest AGB density and stock of other main countries in each continent were listed in Table 3 and Table S3.

Table 3. The continental-level and national-level forest AGB density and biomass stock in this study.

\begin{tabular}{cccc}
\hline Continent & Mean AGB $\mathbf{( M g} / \mathbf{h a})$ & Forest Area (Mha) & Total AGB (Pg) \\
\hline Africa & $333.34 \pm 63.80$ & 191.0 & 64.65 \\
Asia & $172.28 \pm 94.75$ & 762.2 & 143.14 \\
Australia & $415.66 \pm 131.75$ & 20.3 & 8.69 \\
North America & $166.48 \pm 84.97$ & 459.1 & 77.46 \\
Oceania & $424.30 \pm 114.03$ & 21.9 & 9.30 \\
South America & $301.68 \pm 67.43$ & 608.6 & 188.68 \\
Europe & $132.97 \pm 50.70$ & 310.1 & 40.83 \\
\hline Country & Mean AGB (Mg/ha) & Forest Area (Mha) & Total AGB (Pg) \\
\hline Australia & $415.85 \pm 131.69$ & 20.28 & 8.68 \\
Brazil & $306.79 \pm 36.1$ & 317.34 & 97.44 \\
Canada & $141.38 \pm 64.68$ & 268.81 & 38.26 \\
China & $160.74 \pm 45.16$ & 101.34 & 16.41 \\
Republic of the Congo & $342.01 \pm 49.17$ & 103.66 & 35.52 \\
Finland & $89.42 \pm 7.99$ & 15.51 & 1.37 \\
Indonesia & $328.25 \pm 43.39$ & 102.78 & 34.04 \\
Japan & $175.78 \pm 41.69$ & 22.83 & 4.03 \\
New Zealand & $488.69 \pm 107.94$ & 12.24 & 6.07 \\
Norway & $210.15 \pm 116.76$ & 9.04 & 1.95 \\
Russian Federation & $110.14 \pm 23.48$ & 530.48 & 59.87 \\
Sweden & $108.11 \pm 16.39$ & 26.32 & 2.82 \\
United Kingdom & $265.09 \pm 87.3$ & 3.22 & 0.87 \\
United States & $180.96 \pm 92.44$ & 150.61 & 27.71 \\
\hline
\end{tabular}

The uncertainty in the AGB estimation introduced by the plot location for each pixel was evaluated using the standard deviation of the 100 sets of initial forest AGB estimation maps (Figure $4 \mathrm{~b}, \mathrm{c}$ ). The mean uncertainty introduced by the plot location was $14.53 \mathrm{Mg} / \mathrm{ha}$ with a range of 3.75-127.69 Mg/ha. Most forests distributed in the European, North American, and Amazon areas had relatively low uncertainty values ( $<30 \mathrm{Mg} / \mathrm{ha})$. In Southeast Asia, the influence of plot location uncertainty became larger, resulting in a forest AGB uncertainty of over $50 \mathrm{Mg} / \mathrm{ha}$. The AGB estimation 
uncertainty introduced by the plot location was highest on the western coast of North America and central Papua New Guinea, reaching values of $100 \mathrm{Mg} / \mathrm{ha}$.

\subsection{Validation at Plot Level}

The retained $30 \%$ of independent plot measurements were used to evaluate the forest AGB estimation result at the plot scale. As can be seen in Figure 5, the estimated forest AGB map showed good agreement with the field-measured AGB. The fitted line between the observed values and predicted values was close to the 1:1 line. The statistical parameters also show that the accuracy of the estimated global forest AGB map was satisfactory. The $R^{2}$ between the observed and predicted AGB was 0.56 and the RMSE was $87.53 \mathrm{Mg} / \mathrm{ha}$. However, the global forest AGB map had some limitations. It was inclined to overestimate forest AGB density in areas with low AGB density ( $<221 \mathrm{Mg} / \mathrm{ha})$, and underestimate forest AGB density in areas with relatively high AGB density ( $>221 \mathrm{Mg} / \mathrm{ha}$ ).

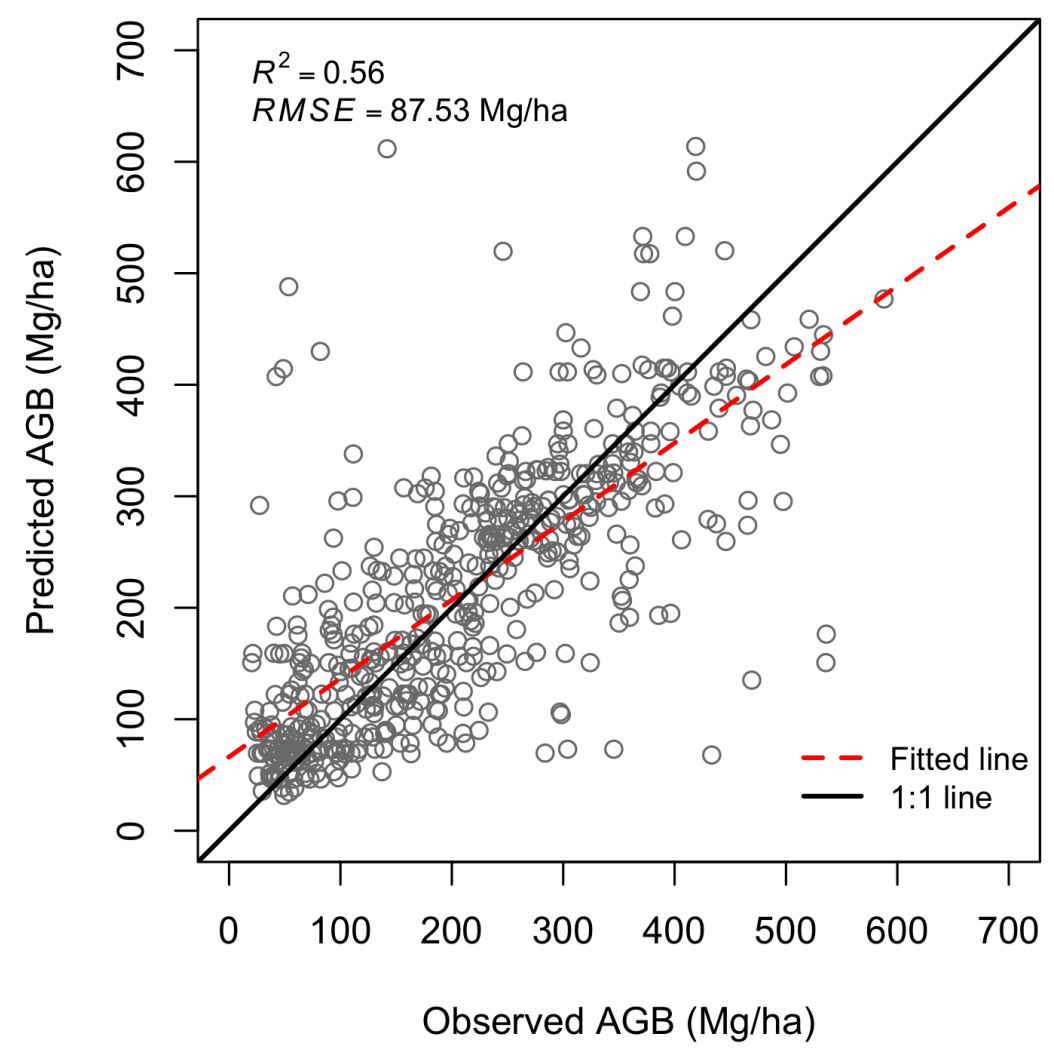

Figure 5. Evaluation of predicted forest AGB using validation ground inventory dataset at the plot level. $R^{2}$ represents the adjusted coefficient of determination, RMSE represents the root-mean-square error.

At the ecoregion zone level, the forest AGB map was compared with by the AGB density values of the eight ecological zones in different continents provided by the IPCC. As shown in Figure 6, the $R^{2}$ and RMSE between the IPCC suggested values and the predicted AGB were 0.38 and $101.21 \mathrm{Mg} / \mathrm{ha}$, respectively. However, there was a clear outlier where the predicted forest AGB density for the North America temperate oceanic forest was significantly lower than the value provided by the IPCC. When we removed this data point, the $R^{2}$ increased to 0.56 and the RMSE decreased to $82.38 \mathrm{Mg} / \mathrm{ha}$, which was very close to the plot-level validation results. 


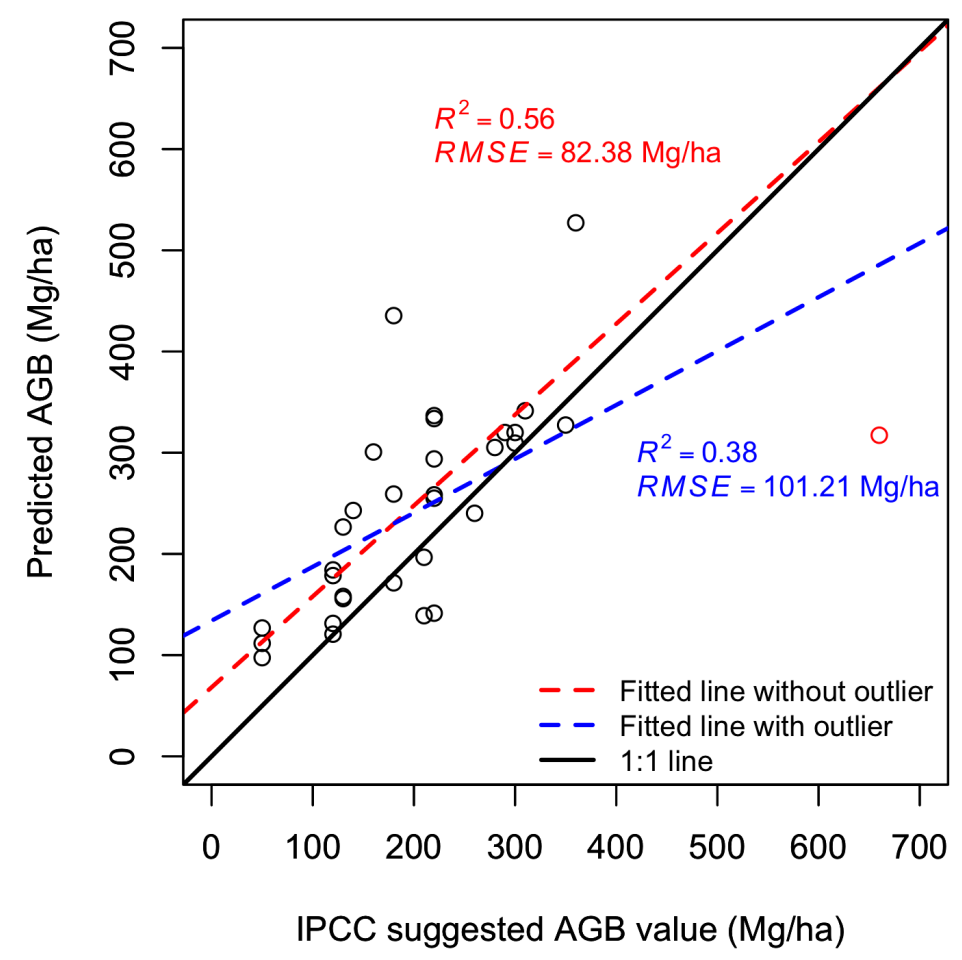

Figure 6. Comparison of the predicted forest AGB with IPCC suggested values at the ecological zone level. The outlier is the temperate oceanic forest in North America. $R^{2}$ represents the adjusted coefficient of determination, and RMSE represents the root-mean-square error.

\subsection{Comparisons with Published Regional Forest AGB Maps}

\subsubsection{Pan-Tropical Forests}

Figure 7 shows the pixel-level differences between our forest AGB map and the products from Saatchi et al. (2011) [48], Baccini et al. (2012) [49], Avitabile et al. (2015) [72], and Ruesch \& Gibbs (2008) [73]. In general, our forest AGB density values tended to be higher ( $80 \mathrm{Mg} / \mathrm{ha}$ on average) than those from Saatchi et al. (2011) [48] (Figure 7a), especially in the Amazon Basin and eastern Democratic Republic of Congo. In South and Southeast Asia, differences between the two products were mixed, with positive and negative values. The FN index map (Figure 8a) showed that the two products had high similarity in spatial patterns. Over $59 \%$ of the pixels had a FN index value larger than 70. The differences between our product and that from Baccini et al. (2012) [49] and Avitabile et al. (2015) [72] were similar (Figure 7b,c). Our product tended to be slightly higher than these two products, and the average differences were both around $65 \mathrm{Mg} / \mathrm{ha}$. However, the standard deviation of differences between our product and that of Baccini et al. (2012) [49] was smaller than between our product and the product of Avitabile et al. (2015) [72], at $77.07 \mathrm{Mg} / \mathrm{ha}$ and $107.40 \mathrm{Mg} / \mathrm{ha}$, respectively. The spatial similarity among these three products was also similar. The average FN index between our product and that from Baccini et al. (2012) [49] was 75.32, and the average FN index between our product and that from Avitabile et al. (2015) [72] was 65.80. However, the spatial similarity between our product and that from Avitabile et al. (2015) [72] was relatively poor in Central America and south of the Amazon Basin. Finally, our product tended to be lower than the product from Ruesch \& Gibbs (2008) [73], especially in the Amazon Basin and the tropical areas of Central Africa. The average difference between the two products was $-12 \mathrm{Mg} / \mathrm{ha}$. The average value of the FN index was 76.37, which indicated these two products also had high spatial similarity. However, the spatial similarity in Southeast and South Asia was relatively poor compared with that in the Amazon Basin and Central Africa (Figure 8d). 


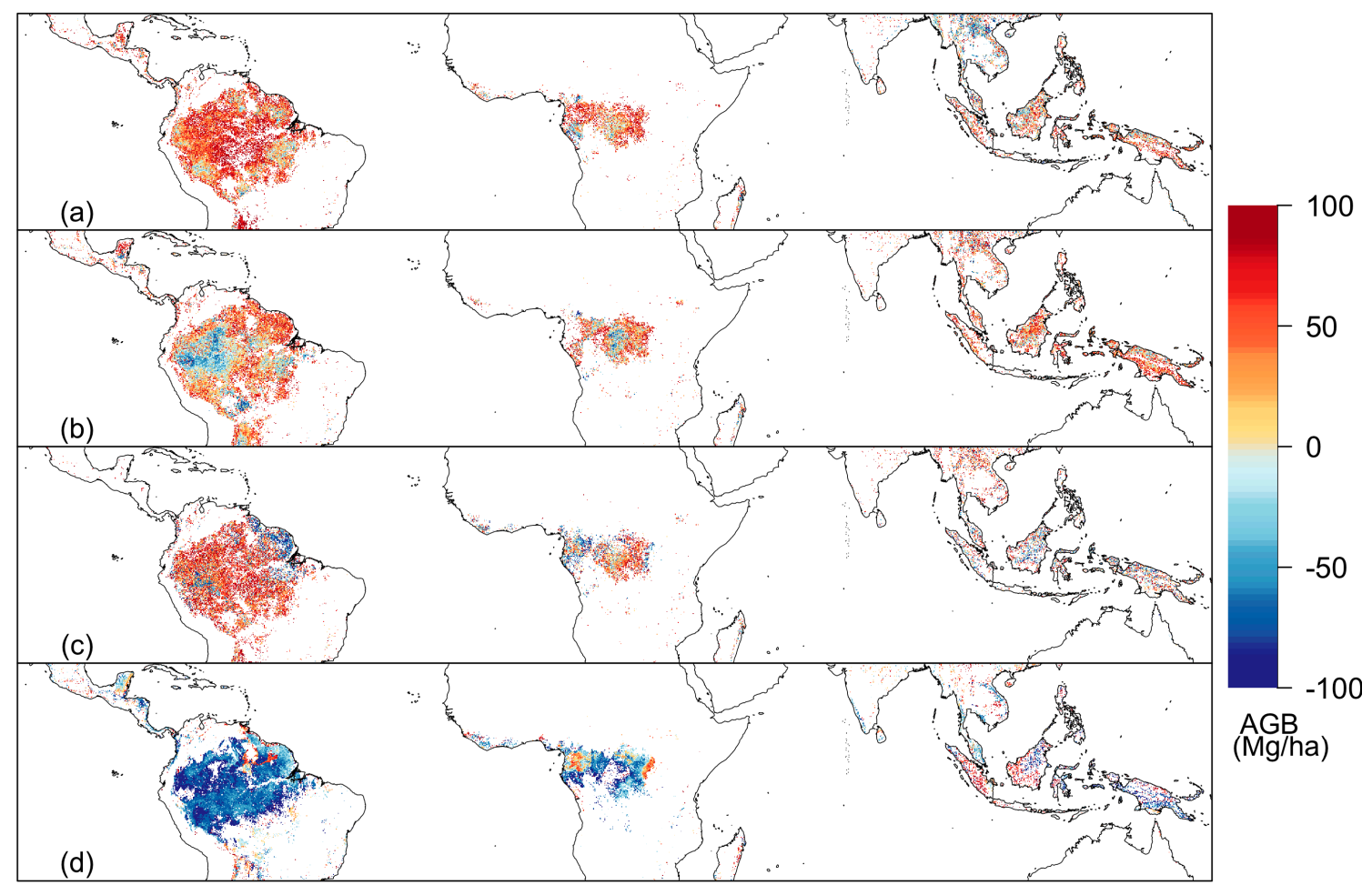

Figure 7. The difference map between our global wall-to-wall forest AGB product and the products from (a) Saatchi et al. (2011) [48]; (b) Baccini et al. (2012) [49]; (c) Avitabile et al. (2015) [72]; and (d) Reusch \& Gibbs (2008) [73] in pan-tropical forest areas.

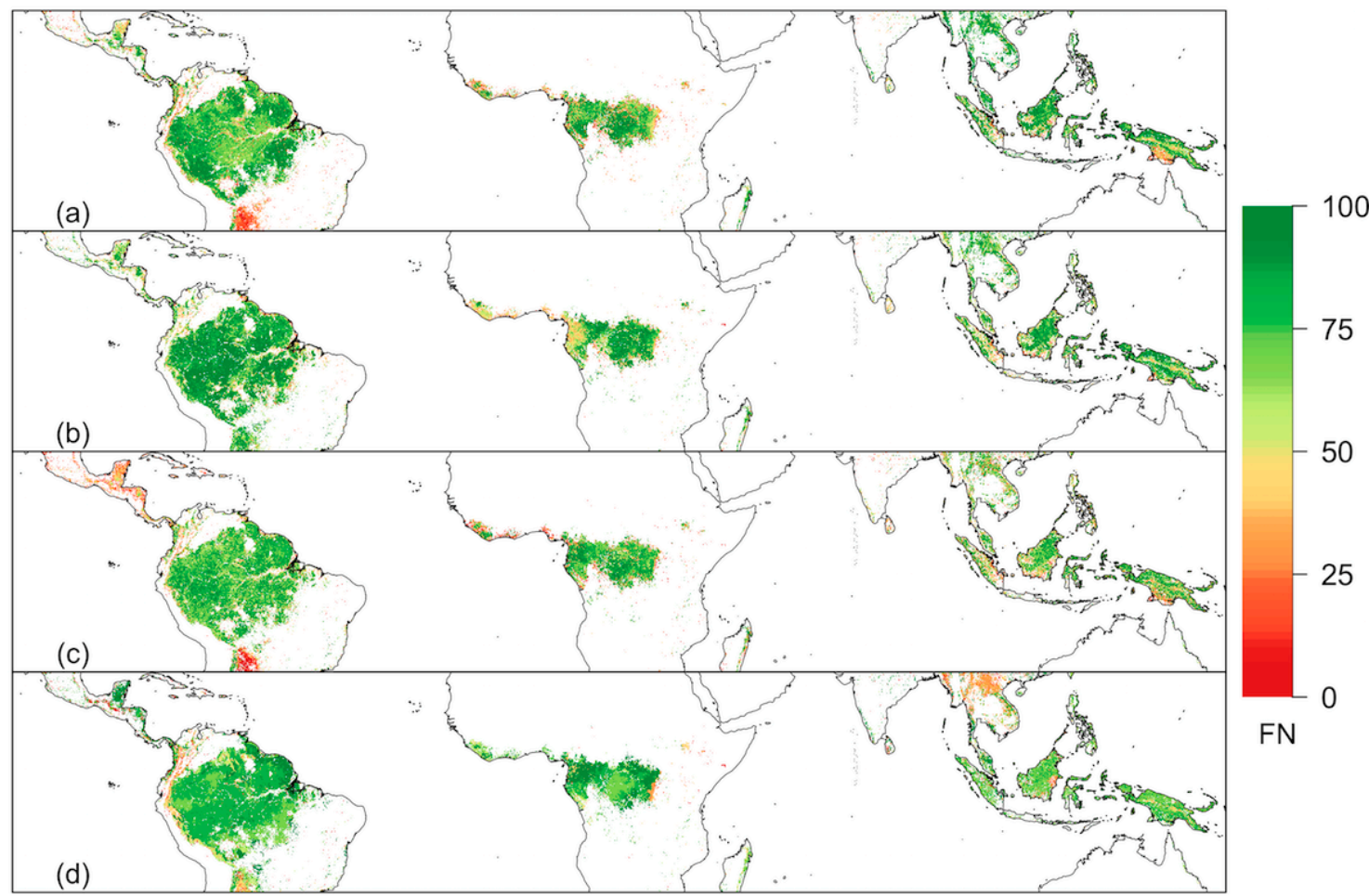

Figure 8. The spatial similarity map between our global wall-to-wall forest AGB product and the products from (a) Saatchi et al. (2011) [48]; (b) Baccini et al. (2012) [49]; (c) Avitabile et al. (2015) [72]; and (d) Reusch \& Gibbs (2008) [73] in pan-tropical forest areas. 


\subsubsection{Boreal Forests}

In boreal forest areas, our wall-to-wall forest AGB map was compared with three products in northern America [54,73,74] and three products in northern Eurasia [54,73,75]. In northern America (Figure 9), our product tended to be higher than all three products, except for the difference between our product and that of Ruesch \& Gibbs et al. (2008) [73] in the eastern U.S. The average differences between our product and the products of Margolis et al. (2015) [75], Thurner et al. (2014) [54], and Ruesch \& Gibbs (2008) [73] were $56 \mathrm{Mg} / \mathrm{ha}, 96 \mathrm{Mg} / \mathrm{ha}$ and $75 \mathrm{Mg} / \mathrm{ha}$, respectively. The average FN index for the product of Margolis et al. (2015) [75] was 55.76, which was the highest among the three products (Figure 10). The spatial similarity between our product and the products of Thurner et al. (2014) [54] and Ruesch \& Gibbs (2008) [73] was relatively poor.

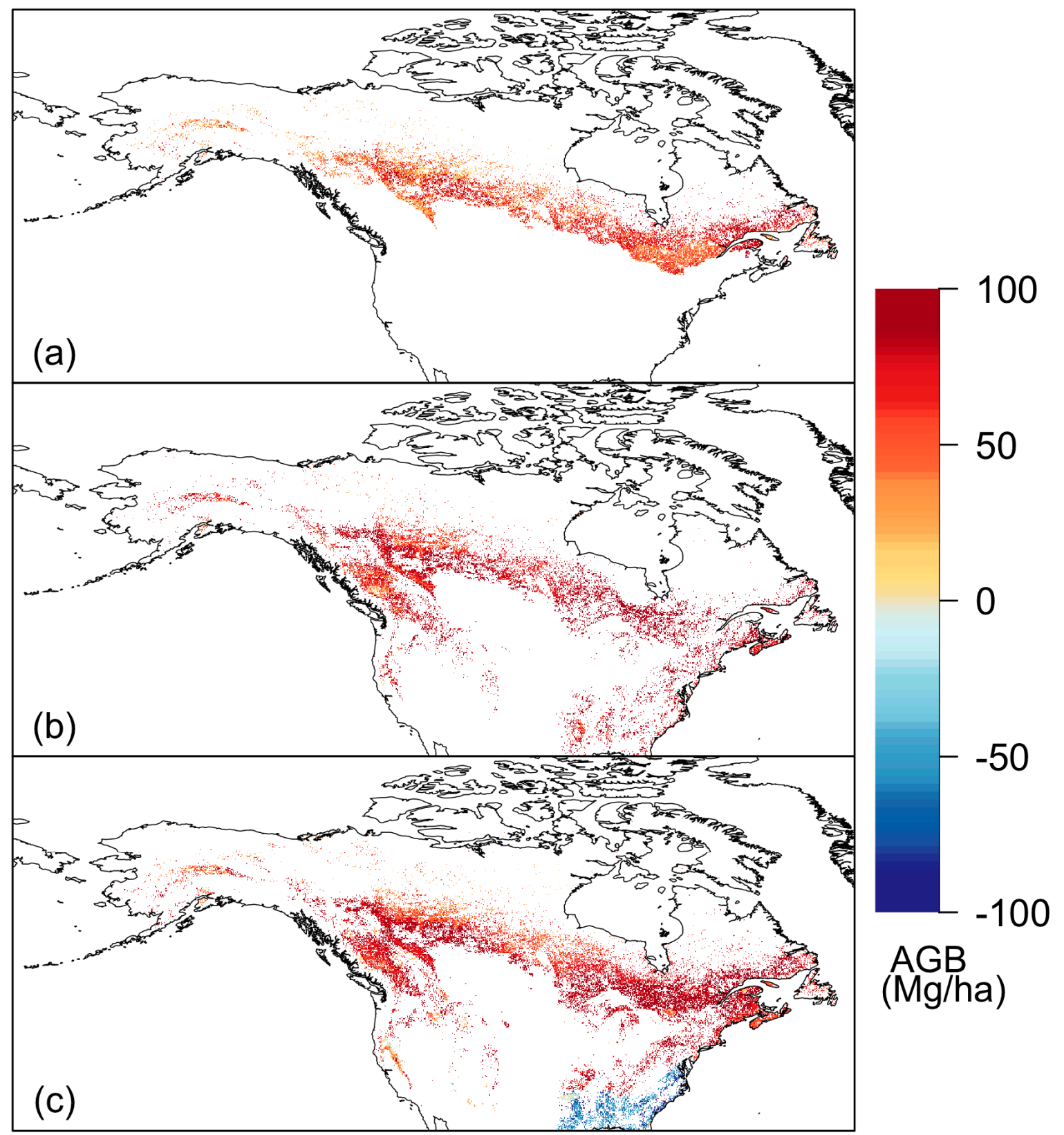

Figure 9. The difference map between our global wall-to-wall forest AGB product and the products from (a) Margolis et al. (2015) [74]; (b) Thurner et al. (2014) [54]; and (c) Reusch \& Gibbs (2008) [73] in the North America forest area. 


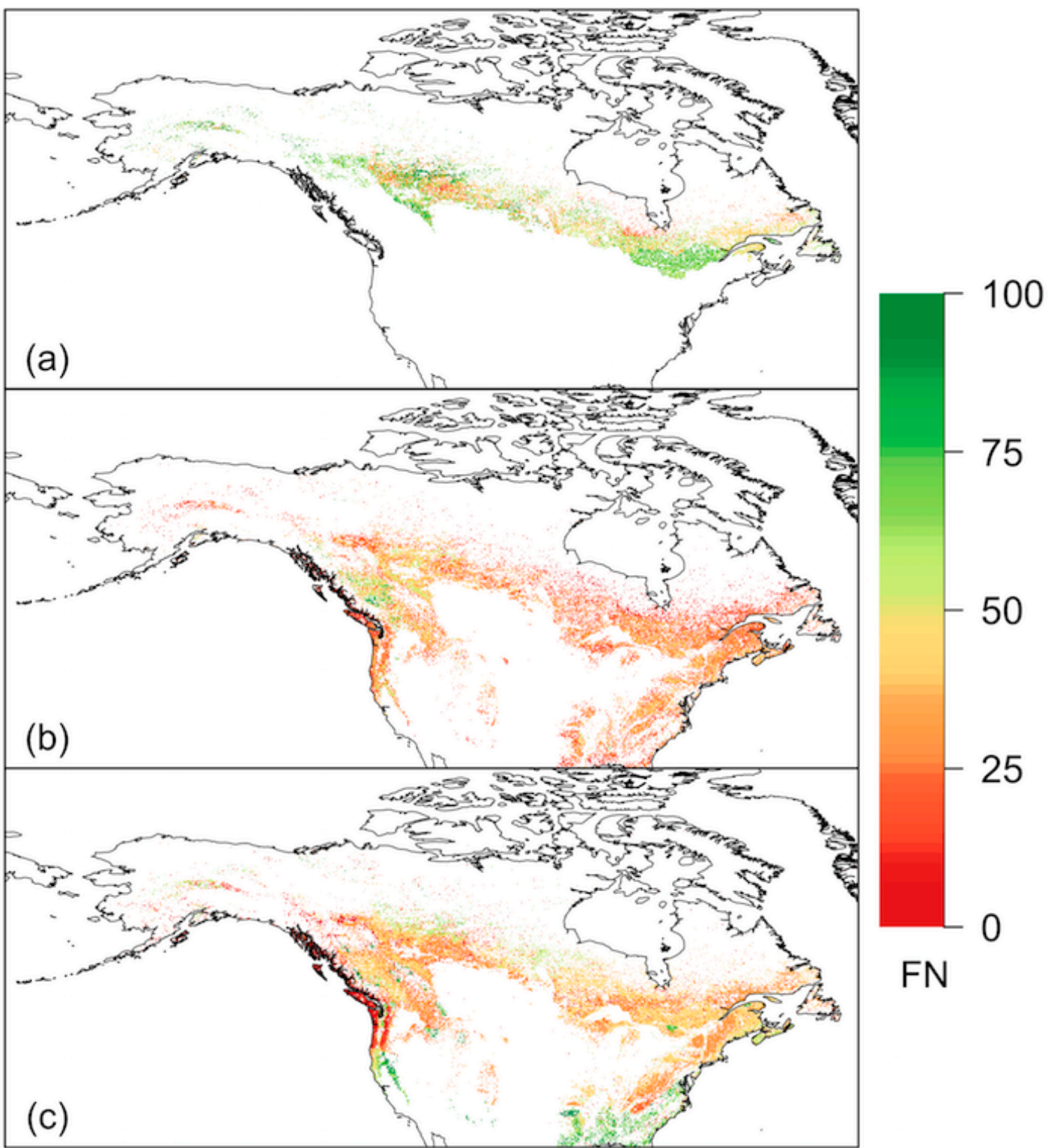

Figure 10. The spatial similarity map between our global wall-to-wall forest AGB product and the products from (a) Margolis et al. (2015) [74]; (b) Thurner et al. (2014) [54]; and (c) Reusch \& Gibbs (2008) [73] in the North America boreal forest area.

Our product also tended to be higher than all three products in northern Eurasia (Figure 11). The average differences between our product and the products of Neigh et al. (2015) [74], Thurner et al. (2014) [54], and Ruesch \& Gibbs et al. (2014) [73] were $36 \mathrm{Mg} / \mathrm{ha}, 72 \mathrm{Mg} / \mathrm{ha}$ and $71 \mathrm{Mg} / \mathrm{ha}$, respectively. Nearly all pixels had positive differences between our product and these three products, except those between our product and the product of Neigh et al. (2015) [74] in central northern Eurasian areas. Among these three products, the spatial similarity between our product and that from Neigh et al. (2015) [74] was the highest (Figure 12). The average FN index between these two products was 59.27. The spatial similarities between our product and the products from Thurner et al. (2014) [54] and Ruesch \& Gibbs (2008) [73] were relatively poor. Over $83.24 \%$ pixels of the FN index map between our product and the product from Thurner et al. (2014) [54] were lower than 50. The FN index between our product and the product of Ruesch \& Gibbs (2008) [73] was more unevenly distributed. 


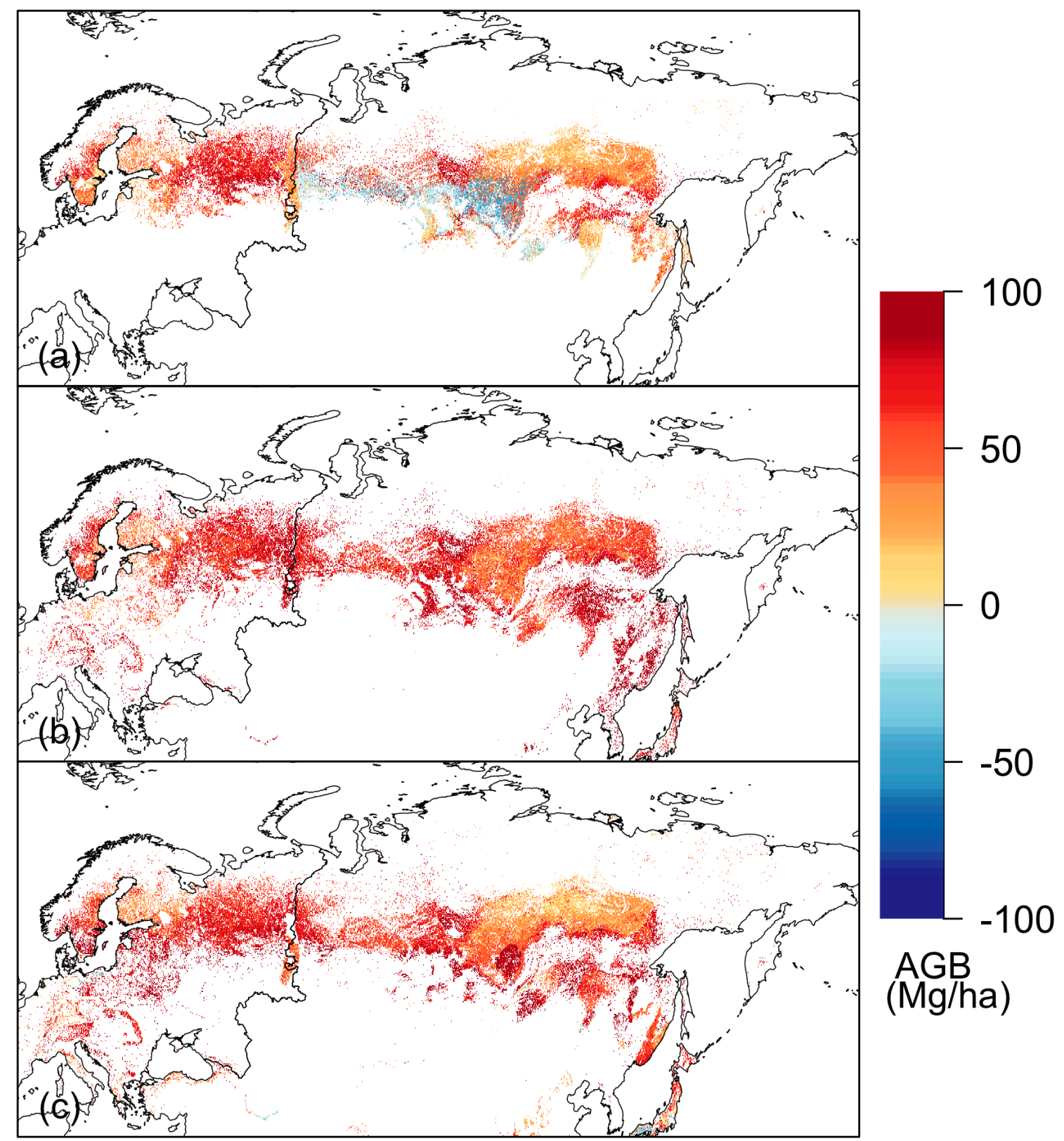

Figure 11. The difference map between our global wall-to-wall forest AGB product and the products from (a) Neigh et al. (2015) [75]; (b) Thurner et al. (2014) [54]; and (c) Reusch \& Gibbs (2008) [73] in the northern Eurasia boreal forest area. 


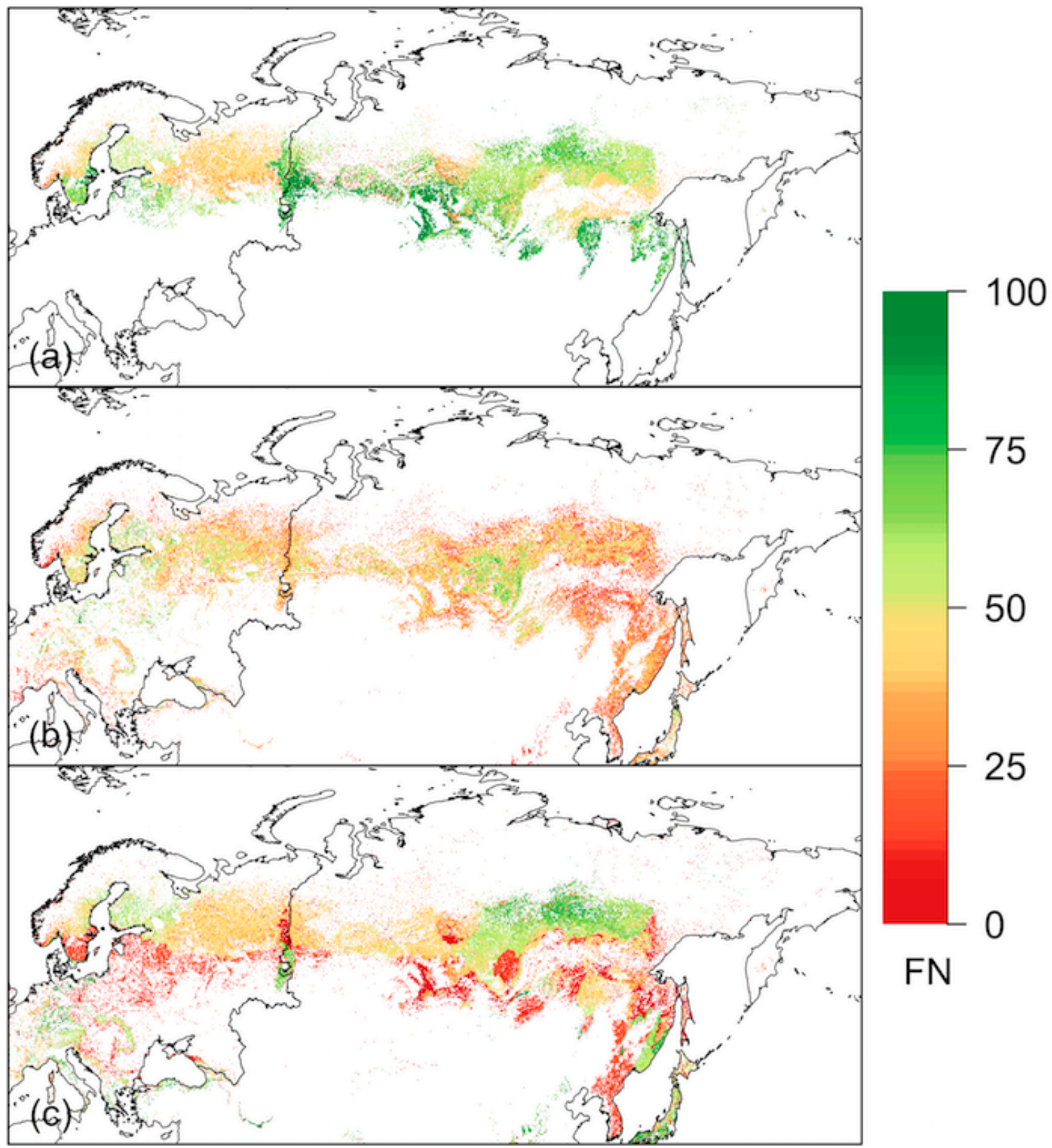

Figure 12. The spatial similarity map between our global wall-to-wall forest AGB product and the products from (a) Neigh et al. (2015) [75]; (b) Thurner et al. (2014) [54]; and (c) Reusch \& Gibbs (2008) [73] in the northern Eurasia boreal forest area.

\subsubsection{U.S. Forests}

Our product was also compared with three nationwide forest AGB products $[73,76,77]$ in the U.S. As can be seen in Figure 13, the average differences between our product and the product of Saatchi et al. (2005) [76] was the smallest among all three products. The differences were mixed with positive and negative values, and the average difference was $24 \mathrm{Mg} / \mathrm{ha}$. The spatial similarity between these two products was also high (Figure 14b). Over 72.18\% of pixels had an FN index higher than 50. Compared with the product of Blackard et al. (2005) [77], our product tended to be slightly higher. About $43.73 \%$ of pixels had differences ranging from $10 \mathrm{Mg} / \mathrm{ha}$ to $50 \mathrm{Mg} / \mathrm{ha}$. The spatial similarity between these two products was the highest (the mean FN index $=67.55$ ). The average differences between our product and that of Ruesch \& Gibbs (2008) [73] were the highest among all three U.S. 
forest AGB products (the mean difference was $71 \mathrm{Mg} / \mathrm{ha}$ ). The variation of differences between these two products was also very high. In the western and northeastern U.S., our product was around 107.60 Mg/ha higher than the product of Ruesch \& Gibbs (2008) on average. However, in the southern eastern U.S., our product was around $42.03 \mathrm{Mg} /$ ha lower than their product on average. The spatial similarity between these two products was also the lowest among all three U.S. forest AGB maps, especially in the western and northeastern U.S.

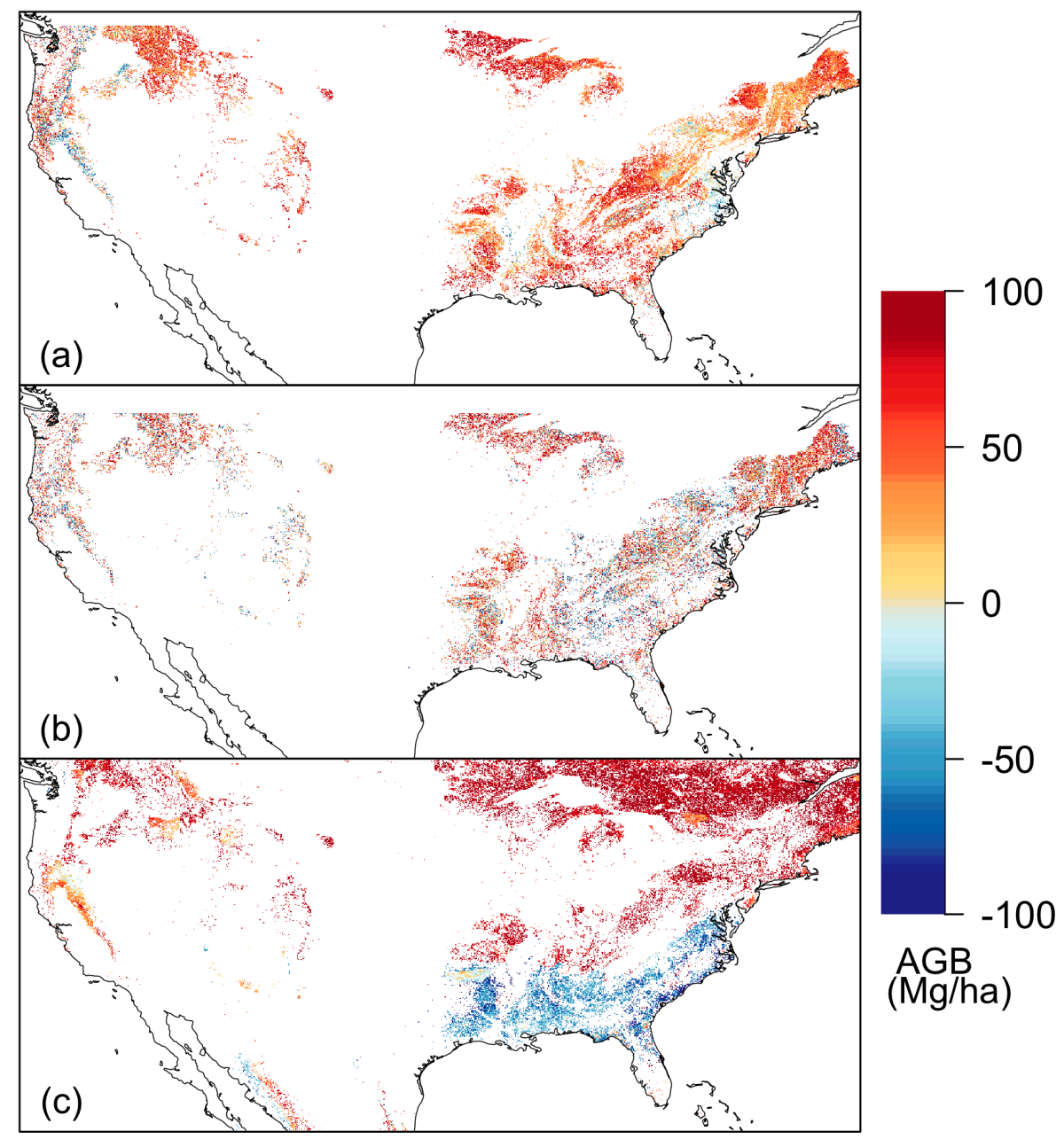

Figure 13. The difference map between our global wall-to-wall forest AGB product and the products from (a) Blackard et al. (2008) [76]; (b) Saatchi et al. (2005) [77]; and (c) Reusch \& Gibbs (2008) [73] in the U.S. forest area. 


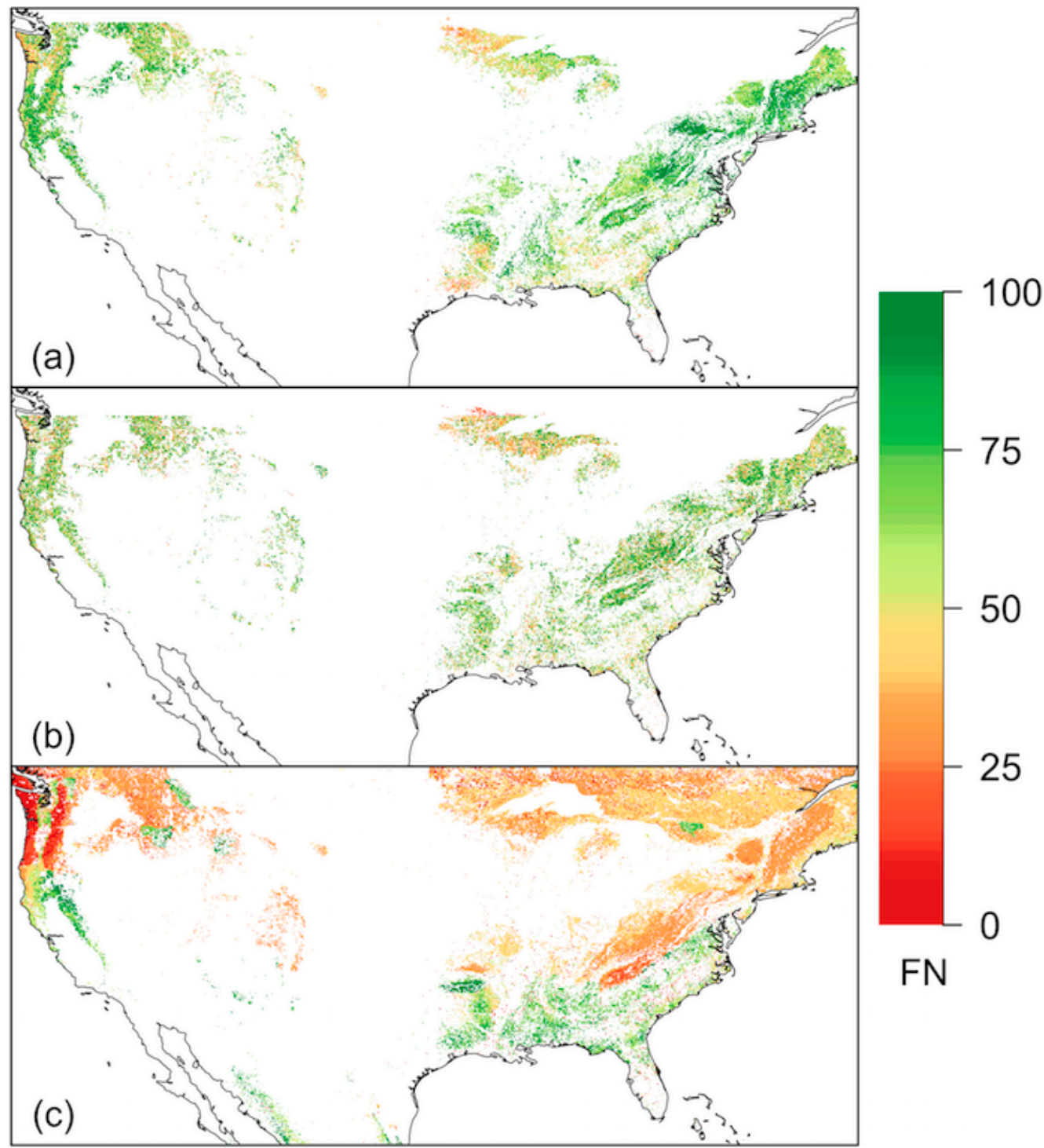

Figure 14. The spatial similarity map between our global wall-to-wall forest AGB product and the products from (a) Blackard et al. (2008) [76]; (b) Saatchi et al. (2005) [77]; and (c) Reusch \& Gibbs (2008) [73] in the U.S. forest area.

\section{Discussion}

The global wall-to-wall forest AGB map obtained from our analysis had good agreement with the independent plot measurements and IPCC-suggested AGB values at the ecoregion level. The trends of forest AGB density along latitude also similar to previous results [12] (Figure 15): the highest AGB density occurred in the temperate latitudes of the Southern hemisphere (southeastern Australia, New Zealand, and Chile), and AGB density decreased from the tropical latitudes to temperate and boreal latitudes of the Northern hemisphere. The high AGB density in the Pacific Northwest of North America brought a significant peak in the trend line of AGB density at the temperate latitudes of the Northern hemisphere (Figure 15). In this study, comparisons between our resulting new map and other published maps were mainly aimed to validate the spatial pattern and AGB level of our result. Therefore, we only conducted direct comparisons based on pixel-level differences. The systematic comparison results showed that our product also had good correspondence in spatial patterns and AGB levels with many of the published products (Table S4; Figure S2). However, our product still had differences with some products in certain areas. 


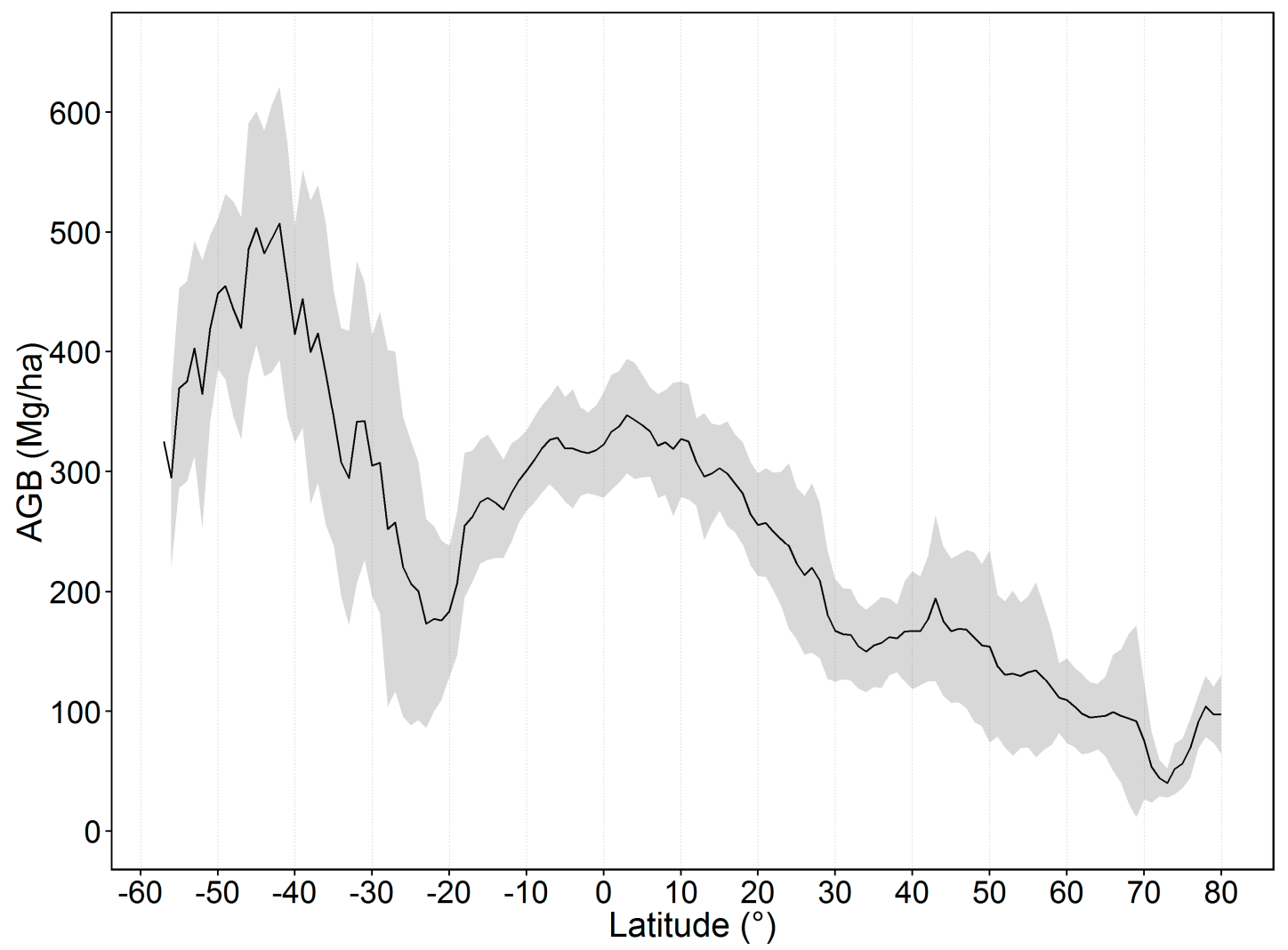

Figure 15. The trend of global forest AGB density along the latitude. The line indicates the mean AGB and grey shadows show the stand deviation of AGB at corresponding latitude.

Saatchi et al. (2011) [48] and Baccini et al. (2012) [49] produced the first two pan-tropical AGB maps using a similar method that integrated GLAS data, optical imagery, and plot data, and Avitabile et al. (2015) [72] fused these two products into a new pan-tropical AGB map using an independent reference dataset of field observations and locally calibrated high-resolution biomass maps. In the western Amazon Basin, our map tended to be slightly higher than the map from Saatchi et al. (2011) [48], but much lower than the map from Baccini et al. (2012) [49] and slightly lower than the map from Avitabile et al. (2015) [72] (Figure 7). In the center of the Amazon Basin, the difference maps were mixed with positive and negative values and our map in general tended to be higher than others (Figure 7). In the northeastern Amazon Basin, our map tended to be higher than Saatchi et al. (2011) [48] and Baccini et al. (2012) [49], but lower than Avitabile et al. (2015) [72] (Figure 7). The spatial difference in AGB in the Amazon Basin between our map and first two pan-tropic AGB maps (Saatchi et al. (2011) [48] and Baccini et al. (2012) [49]) concurred with the results found by Mitchard et al. (2014) [78], who compared these two maps with a map derived from kriging interpolation using 413 field plots. Mitchard et al. (2014) [78] thought that neglecting the regional variations of wood density or D:H (diameter at breast height:height) relationships that cannot be detected by remote sensing was the major reason. We think two factors may have reduced the loss in the information on regional variations of wood density or D:H relationships during our estimation process. First, we directly used the field data from the literature and did not carry out any conversion before the extrapolation, which may keep the potential variations of forest wood density. In contrast, both Saatchi et al. (2011) [48] and Baccini et al. (2012) [49] converted the field AGB into GLAS-derived AGB, which may lose the potential information of forest wood density contained in the plot data. Second, we used bioclimatic layers as inputs in our study, which could potentially be related to wood density [68] or D:H relationships [79] in tropical or global forest areas. The difference map between Avitabile et al. (2015) [72] and Saatchi et al. (2011) [48] 
or Baccini et al. (2012) [49] presented a similar pattern to ours and the map from Mitchard et al. (2014) [78] in the Amazon Basin, which may be benefitted from the fusion with an external field dataset.

Compared with the tropical forest area, most AGB products in the boreal forest areas tended to be lower than our AGB map. We think these differences may result from the following three reasons. First, the underestimation may be caused by the limitation of the remote sensing data used to predict AGB. Thurner et al. (2014) [54] only used the growing stock volume (GSV) product retrieved from SAR (Santoro et al., unpublished data) to predict biomass and their map was lower than other AGB maps in most boreal forest areas. Although Santoro et al. [80] reported GSV was mapped without saturation up to $300 \mathrm{~m}^{3} / \mathrm{ha}$, which is suitable for the boreal forest, the predicted GSV was lower than the reference GSV in their study [80]. This may be the reason for the underestimation in the map from Thurner et al. (2014) [54]. Second, the differences may come from the extrapolation methods. Neigh et al. (2015) [53,74] and Margolis et al. (2015) [75] used the same method to map the boreal forest AGB in northern Eurasia and North America, respectively. They divided the forest AGB into different strata, e.g., conifer, hardwood, mixed wood, and wetlands, using Landsat and MODIS land cover products. The AGB value of each pixel was assigned by the ratio of different strata, the values of which were estimated by combining GLAS, airborne LiDAR and plot data. Since the mean AGB value of a stratum was used while assigning, this may tend to underestimate the AGB density in high AGB areas. Moreover, the strata also included non-forest areas and burned areas, which were not considered in our study. This could also introduce underestimation to their results. Third, the differences may be caused by insufficient number of plot data. In general, the map from Neigh et al. (2015) [74] had high spatial similarity in north Eurasia areas, except northwestern Russia (Figure 12a). This phenomenon may be caused by the AGB estimation model used by Neigh et al. (2015) [74] in the Scandinavian and Russian Taiga, which only linked the airborne LiDAR data with plots of conifer forest in southern Norway. According to the MODIS land cover map (Figure 2), the majority of northwestern Russia is covered by mixed forests and this would introduce an underestimation while applying an AGB model built for conifer forests to mixed forests.

Ruesch \& Gibbs (2008) [73] presented the first global forest biomass map and provided important benchmarks for climate policy dialogues, but they tended to significantly overestimate AGB in tropical areas, and underestimate it in boreal forest areas compared with our product. The negative or positive values in the AGB difference map between Ruesch \& Gibbs (2008) and our map tend to form large patches (Figures 7d and 13c), which is different from other AGB difference maps. The method used by Ruesch \& Gibbs may be the major reason for this phenomenon. Ruesch \& Gibbs (2008) [73] used the global forest AGB default values provided by the IPCC to map forest AGB from a range of spatially explicit climate and vegetation datasets. All the pixels in each ecological zone used the same value, which could not reflect spatial variance in the same ecological zone. Moreover, according to the validation at the ecological zone level (Figure 6), our results were higher than the IPCC value in boreal forest and lower than the value in tropical forest, which was coincident with this phenomenon.

Although the global wall-to-wall forest AGB map has a good correspondence with the independent plot data and nine other published products (in spatial pattern and AGB level), there were deficiencies in this study. First of all, the uncertainty of the forest AGB map was not fully quantified. In this study, we only computed the uncertainty caused by the plot location uncertainty, but there are other error sources from the uncertainty of each prediction variables. Generally, the propagation of the uncertainty from each prediction variable to the final forest AGB estimation uncertainty was evaluated using the Monte Carlo simulation method assuming the influences of each variable are independent. However, to conduct this, thousands of RF runs need to be executed to estimate the uncertainty of the extrapolated GLAS parameters and the final forest AGB product. Each run will need to take a week to finish. Considering the time and computation cost, we only evaluated the uncertainty caused by plot location in the current study and other uncertainties will be fulfilled in the future study. Second, the quality of reference data still needs improvements in future research. Currently, temporal mismatch between our ground inventory data and remote sensing data was a potential error source. The collected 
ground plots were spanned from 1990 to 2013 while the prediction variables were collected in 2004 . During this long time (up to 14 year) span, the condition in some plots would be changed due to the land cover/use change, forest growth, or heavy degradation. However, currently, we do not have enough ground plots from a single year (e.g., 2004) to build a robust global forest AGB estimated model. There is a tradeoff between temporal match and quantity control in current collected plots at the global scale. We will continue to work on collecting more ground measurements to address this issue. Moreover, there was also a deficiency to use plot AGB values to represent the biomass at $1 \mathrm{~km}$ resolution. The difference between the plot size and the resolution of prediction variables may be another source of error in the final result. Airborne LiDAR has been recognized as an important method to extrapolate plot biomass into grids with high accuracy [45]. In the future, it would be a practical option to first use airborne LiDAR to extrapolate plot measurements into regional scale and then use the airborne LiDAR derived AGB as the ground truth input of the proposed method in this study. Third, the seasonality of GLAS data should be considered in the further research. In the temperate deciduous forest, GLAS waveforms from the summer and early stage of autumn period can well capture the returns from forest canopy [81]. By contrast, data from other periods received less signals from forest canopy and did not effectively reflect forest height [81]. Since all GLAS data in 2004 were used in this study, it may introduce some uncertainty to the final AGB results in the temperate forest areas.

Global forest ecosystems are important land surface carbon sinks which greatly influence the global carbon cycle [1,2]. Since forest AGB is a direct measurement of the forest carbon stock, it is of great significance to accurately map the global forest AGB distribution. To the best of our knowledge, this study, for the first time, mapped the global continuous forest AGB distribution using remotely sensed observation data and a large amount of plot estimations. The resulting map can help researchers to improve the accuracy of global carbon cycle modelling, enhance our understanding on global carbon dynamics, and quantify anthropogenic carbon dioxide emissions.

\section{Conclusions}

This study produced a global wall-to-wall forest AGB map at a 1-km resolution for the first time, and this new product is available through the web [55]. This product was generated based on the framework proposed by Su et al. (2016) [46] and over 4000 plot measurement records collected from published literature. Based on this forest AGB product, the global forest AGB density was around $210 \mathrm{Mg} / \mathrm{ha}$ on average with a standard deviation of $109 \mathrm{Mg} / \mathrm{ha}$. The uncertainty introduced by plot location was $14.53 \mathrm{Mg} / \mathrm{ha}$ on average with a range of $3.75-127.69 \mathrm{Mg} / \mathrm{ha}$. This product was evaluated at the plot level and the result showed that our products had a good correspondence with the independent plot measurements $\left(R^{2}=0.56 R M S E=87.53 \mathrm{Mg} / \mathrm{ha}\right)$. At the ecoregion level, values recommended by the IPCC were used to compare with this new map which also showed a good correspondence $\left(R^{2}=0.38 R M S E=101.21 \mathrm{Mg} /\right.$ ha with one outlier, $R^{2}=0.56 R M S E=82.38 \mathrm{Mg} / \mathrm{ha}$ after removing one outlier). Moreover, a systematic comparison between our product and other published regional products was conducted in pan-tropical areas, northern boreal forest areas, and the U.S. This comparison was aimed to compare the spatial similarity in AGB distribution and AGB level between our map and other published maps. The results indicated our product corresponded well with products obtained by integrating LiDAR data. Products generated using traditional optical passive remote sensing and radar data tended to underestimate forest AGB density. This new map is highly beneficial to global carbon assessments and biogeochemical modellings. Moreover, it can also help to quantify changes in forest biomass caused by deforestation or afforestation.

Supplementary Materials: The following are available online at www.mdpi.com/2072-4292/8/7/565/s1, Table S1: The main literature provided the AGB using allometry equation; Table S2: The distribution of plots in each continents and ecoregions; Table S3: The national level forest AGB density and biomass stock in this study; Table S4: The mean AGB and FN differences for each major region; Figure S1: The mean importance of variables for 100 runs AGB estimation RandomForest model, indicated by percentage increase of mean-squared error (\%IncMSE) (left) and the increase in node purity (IncNodePurity) (right). le, we, te, prec_total, precp_s, 
tmean, T_s, ndvi, and landuse represent the leading edge extent, waveform extent, trailing edge extent, annual total precipitation, annual precipitation seasonality, annual mean temperature, annual temperature seasonality, cumulative NDVI, and landcover type, respectively; Figure S2: validation of AGB map at different ecoregions.

Acknowledgments: This study is supported by the National Key Basic Research Program of China (project number 2013CB956604), National Science Foundation of China (project numbers 41471363 and 31270563), and National Science Foundation (DBI 1356077). We thank the United States Geological Survey and National Aeronautics and Space Administration for providing the SRTM DEM products.

Author Contributions: Tianyu Hu, Yanjun Su and Qinghua Guo designed the experiment; Baolin Xue, Jin Liu and Xiaoqian Zhao collected the required data; Tianyu Hu and Yanjun Su performed the experiment; Tianyu Hu, Yanjun Su and Baolin Xue conducted the analysis of the results; Tianyu Hu, Yanjun Su, Jingyun Fang and Qinghua Guo contributed towards writing the manuscript.

Conflicts of Interest: The authors declare no conflict of interest.

\section{Abbreviations}

The following abbreviations are used in this manuscript:

$\begin{array}{ll}\text { AGB } & \text { aboveground biomass } \\ \text { LiDAR } & \text { Light Detection and Ranging } \\ \text { GLAS } & \text { Geoscience Laser Altimeter System } \\ \text { ICESat } & \text { Ice, Cloud, and Land Elevation Satellite } \\ R^{2} & \text { adjusted coefficient of determination } \\ \text { RMSE } & \text { root-mean-square error } \\ \text { SAR } & \text { Synthetic Aperture Radar } \\ \text { NDVI } & \text { Normalized Difference Vegetation Index } \\ \text { LP DAAC } & \text { Land Processes Distributed Active Archive Center } \\ \text { SRTM } & \text { Shuttle Radar Topographic Mission } \\ \text { CGIAR-CSI } & \text { Consultative Group for International Agricultural Research-Consortium for Spatial Information } \\ \text { DEM } & \text { digital elevation model } \\ \text { RF } & \text { random forest } \\ \text { FN } & \text { fuzzy numerical } \\ \text { H } & \text { tree height } \\ \text { DBH,D } & \text { diameter at breast height } \\ \text { GSV } & \text { growing stock volume }\end{array}$

\section{References}

1. Arneth, A.; Harrison, S.P.; Zaehle, S.; Tsigaridis, K.; Menon, S.; Bartlein, P.J.; Feichter, J.; Korhola, A.; Kulmala, M.; O'donnell, D. Terrestrial biogeochemical feedbacks in the climate system. Nat. Geosci. 2010, 3, 525-532. [CrossRef]

2. Bonan, G.B. Forests and climate change: Forcings, feedbacks, and the climate benefits of forests. Science 2008, 320, 1444-1449. [CrossRef] [PubMed]

3. Drake, J.B.; Knox, R.G.; Dubayah, R.O.; Clark, D.B.; Condit, R.; Blair, J.B.; Hofton, M. Above-ground biomass estimation in closed canopy neotropical forests using lidar remote sensing: Factors affecting the generality of relationships. Glob. Ecol. Biogeogr. 2003, 12, 147-159. [CrossRef]

4. Foley, J.A.; Prentice, I.C.; Ramankutty, N.; Levis, S.; Pollard, D.; Sitch, S.; Haxeltine, A. An integrated biosphere model of land surface processes, terrestrial carbon balance, and vegetation dynamics. Glob. Biogeochem. Cycle 1996, 10, 603-628. [CrossRef]

5. Friend, A.; Stevens, A.; Knox, R.; Cannell, M. A process-based, terrestrial biosphere model of ecosystem dynamics (hybrid v3. 0). Ecol. Model. 1997, 95, 249-287. [CrossRef]

6. Hurtt, G.C.; Moorcroft, P.; Pacala, S.W.; Levin, S.A. Terrestrial models and global change: Challenges for the future. Glob. Chang. Biol. 1998, 4, 581-590. [CrossRef]

7. Potter, C.S. Terrestrial biomass and the effects of deforestation on the global carbon cycle results from a model of primary production using satellite observations. BioScience 1999, 49, 769-778. [CrossRef]

8. Houghton, R.A. Tropical deforestation and atmospheric carbon dioxide. In Tropical Forests and Climate; Springer: Dordrecht, The Netherlands, 1992; pp. 99-118.

9. Houghton, R.; Lawrence, K.; Hackler, J.; Brown, S. The spatial distribution of forest biomass in the brazilian amazon: A comparison of estimates. Glob. Chang. Biol. 2001, 7, 731-746. [CrossRef] 
10. Bunker, D.E.; DeClerck, F.; Bradford, J.C.; Colwell, R.K.; Perfecto, I.; Phillips, O.L.; Sankaran, M.; Naeem, S. Species loss and aboveground carbon storage in a tropical forest. Science 2005, 310, 1029-1031. [CrossRef] [PubMed]

11. Galbraith, D.; Levy, P.E.; Sitch, S.; Huntingford, C.; Cox, P.; Williams, M.; Meir, P. Multiple mechanisms of amazonian forest biomass losses in three dynamic global vegetation models under climate change. New Phytol. 2010, 187, 647-665. [CrossRef] [PubMed]

12. Keith, H.; Mackey, B.G.; Lindenmayer, D.B. Re-evaluation of forest biomass carbon stocks and lessons from the world's most carbon-dense forests. Proc. Natl. Acad. Sci. USA 2009, 106, 11635-11640. [CrossRef] [PubMed]

13. Pan, Y.; Birdsey, R.A.; Fang, J.; Houghton, R.; Kauppi, P.E.; Kurz, W.A.; Phillips, O.L.; Shvidenko, A.; Lewis, S.L.; Canadell, J.G.; et al. A large and persistent carbon sink in the world's forests. Science 2011, 333, 988-993. [CrossRef] [PubMed]

14. Fang, J.; Chen, A.; Peng, C.; Zhao, S.; Ci, L. Changes in forest biomass carbon storage in china between 1949 and 1998. Science 2001, 292, 2320-2322. [CrossRef] [PubMed]

15. Malhi, Y.; Phillips, O.; Lloyd, J.; Baker, T.; Wright, J.; Almeida, S.; Arroyo, L.; Frederiksen, T.; Grace, J.; Higuchi, N. An international network to monitor the structure, composition and dynamics of amazonian forests (rainfor). J. Veg. Sci. 2002, 13, 439-450. [CrossRef]

16. Houghton, R. Aboveground forest biomass and the global carbon balance. Glob. Chang. Biol. 2005, 11, 945-958. [CrossRef]

17. Cohen, W.B.; Harmon, M.E.; Wallin, D.O.; Fiorella, M. Two decades of carbon flux from forests of the pacific northwest. BioScience 1996, 46, 836-844. [CrossRef]

18. Running, S.; Baldocchi, D.; Turner, D.; Gower, S.; Bakwin, P.; Hibbard, K. A global terrestrial monitoring network integrating tower fluxes, flask sampling, ecosystem modeling and eos satellite data. Remote Sens. Environ. 1999, 70, 108-127. [CrossRef]

19. Woodcock, C.E.; Collins, J.B.; Gopal, S.; Jakabhazy, V.D.; Li, X.; Macomber, S.; Ryherd, S.; Harward, V.J.; Levitan, J.; Wu, Y. Mapping forest vegetation using landsat tm imagery and a canopy reflectance model. Remote Sens. Environ. 1994, 50, 240-254. [CrossRef]

20. Fazakas, Z.; Nilsson, M.; Olsson, H. Regional forest biomass and wood volume estimation using satellite data and ancillary data. Agric. For. Meteorol. 1999, 98, 417-425. [CrossRef]

21. Foody, G.M.; Cutler, M.E.; Mcmorrow, J.; Pelz, D.; Tangki, H.; Boyd, D.S.; Douglas, I. Mapping the biomass of bornean tropical rain forest from remotely sensed data. Glob. Ecol. Biogeogr. 2001, 10, 379-387. [CrossRef]

22. Sader, S.A.; Waide, R.B.; Lawrence, W.T.; Joyce, A.T. Tropical forest biomass and successional age class relationships to a vegetation index derived from landsat tm data. Remote Sens. Environ. 1989, 28, 143-198. [CrossRef]

23. Baccini, A.; Laporte, N.; Goetz, S.; Sun, M.; Dong, H. A first map of tropical africa's above-ground biomass derived from satellite imagery. Environ. Res. Lett. 2008, 3, 045011. [CrossRef]

24. Luckman, A.; Baker, J.; Kuplich, T.M.; Yanasse, C.D.C.F.; Frery, A.C. A study of the relationship between radar backscatter and regenerating tropical forest biomass for spaceborne sar instruments. Remote Sens. Environ. 1997, 60, 1-13. [CrossRef]

25. Toan, T.; Beaudoin, A.; Riom, J.; Guyon, D. Relating forest biomass to sar data. IEEE Trans. Geosci. Remote 1992, 30, 403-411. [CrossRef]

26. Wagner, W.; Luckman, A.; Vietmeier, J.; Tansey, K. Large-scale mapping of boreal forest in siberia using ers tandem coherence and jers backscatter data. Remote Sens. Environ. 2003, 8, 125-144. [CrossRef]

27. Sun, G.; Ranson, K.J.; Kharuk, V.I. Radiometric slope correction for forest biomass estimation from sar data in the western sayani mountains, siberia. Remote Sens. Environ. 2002, 79, 279-287. [CrossRef]

28. Ranson, K.J.; Sun, G. Mapping biomass of a northern forest using multifrequency sar data. IEEE Trans. Geosci. Remote 1994, 32, 388-396. [CrossRef]

29. Saatchi, S.; Halligan, K.; Despain, D.G.; Crabtree, R.L. Estimation of forest fuel load from radar remote sensing. IEEE Trans. Geosci. Remote 2007, 45, 1726-1740. [CrossRef]

30. Cartus, O.; Santoro, M.; Kellndorfer, J. Mapping forest aboveground biomass in the northeastern united states with alos palsar dual-polarization 1-band. Remote Sens. Environ. 2012, 124, 466-478. [CrossRef]

31. Kasischke, E.S.; Melack, J.M.; Dobson, C.M. The use of imaging radars for ecological applications: A review. Remote Sens. Environ. 1997, 59, 141-156. [CrossRef] 
32. $\mathrm{Lu}, \mathrm{D}$. The potential and challenge of remote sensing-based biomass estimation. Int. J. Remote Sens. 2006, 27, 1297-1328. [CrossRef]

33. Mitchard, E.; Saatchi, S.; Woodhouse, I.; Nangendo, G.; Ribeiro, N.; Williams, M.; Ryan, C.; Lewis, S.; Feldpausch, T.; Meir, P. Using satellite radar backscatter to predict above-ground woody biomass: A consistent relationship across four different african landscapes. Geophys. Res. Lett. 2009, 36, L23401. [CrossRef]

34. Myneni, R.B.; Dong, J.; Tucker, C.J.; Kaufmann, R.K.; Kauppi, P.E.; Liski, J.; Zhou, L.; Alexeyev, V.; Hughes, M. A large carbon sink in the woody biomass of northern forests. Proc. Natl. Acad. Sci. USA 2001, 98, 14784-14789. [CrossRef] [PubMed]

35. Woodhouse, I.H.; Mitchard, E.T.; Brolly, M.; Maniatis, D.; Ryan, C.M. Radar backscatter is not a 'direct measure' of forest biomass. Nat. Clim. Chang. 2012, 2, 556-557. [CrossRef]

36. Su, Y.; Guo, Q. A practical method for srtm dem correction over vegetated mountain areas. ISPRS J. Photogramm. Remote Sens. 2014, 87, 216-228. [CrossRef]

37. Clark, M.L.; Clark, D.B.; Roberts, D.A. Small-footprint lidar estimation of sub-canopy elevation and tree height in a tropical rain forest landscape. Remote Sens. Environ. 2004, 91, 68-89. [CrossRef]

38. Boudreau, J.; Nelson, R.; Margolis, H.; Beaudoin, A.; Guindon, L.; Kimes, D. Regional aboveground forest biomass using airborne and spaceborne lidar in québec. Remote Sens. Environ. 2008, 112, 3876-3890. [CrossRef]

39. Clark, M.L.; Roberts, D.A.; Ewel, J.J.; Clark, D.B. Estimation of tropical rain forest aboveground biomass with small-footprint lidar and hyperspectral sensors. Remote Sens. Environ. 2011, 115, 2931-2942. [CrossRef]

40. Lefsky, M.A.; Harding, D.J.; Keller, M.; Cohen, W.B.; Carabajal, C.C.; Del Bom Espirito-Santo, F.; Hunter, M.O.; de Oliveira, R. Estimates of forest canopy height and aboveground biomass using icesat. Geophys. Res. Lett. 2005, 32, L22S02. [CrossRef]

41. Popescu, S.C.; Zhao, K.; Neuenschwander, A.; Lin, C. Satellite lidar vs. Small footprint airborne lidar: Comparing the accuracy of aboveground biomass estimates and forest structure metrics at footprint level. Remote Sens. Environ. 2011, 115, 2786-2797. [CrossRef]

42. Nelson, R.; Ranson, K.; Sun, G.; Kimes, D.; Kharuk, V.; Montesano, P. Estimating siberian timber volume using modis and icesat/glas. Remote Sens. Environ. 2009, 113, 691-701. [CrossRef]

43. Swatantran, A.; Dubayah, R.; Roberts, D.; Hofton, M.; Blair, J.B. Mapping biomass and stress in the sierra nevada using lidar and hyperspectral data fusion. Remote Sens. Environ. 2011, 115, 2917-2930. [CrossRef]

44. Asner, G.P.; Clark, J.K.; Mascaro, J.; García, G.G.A.; Chadwick, K.D.; Encinales, N.D.A.; Paez-Acosta, G.; Montenegro, C.E.; Kennedy-Bowdoin, T.; Duque, Á.; et al. High-resolution mapping of forest carbon stocks in the colombian amazon. Biogeosciences 2012, 9, 2683-2696. [CrossRef]

45. Li, L.; Guo, Q.; Tao, S.; Kelly, M.; Xu, G. Lidar with multi-temporal modis provide a means to upscale predictions of forest biomass. ISPRS J. Photogramm. Remote Sens. 2015, 102, 198-208. [CrossRef]

46. Simard, M.; Pinto, N.; Fisher, J.B.; Baccini, A. Mapping forest canopy height globally with spaceborne lidar. J. Geophys. Res. Biogeosci. 2011, 116. [CrossRef]

47. Su, Y.; Guo, Q.; Xue, B.; Hu, T.; Alvarez, O.; Tao, S. Spatial distribution of forest aboveground biomass in china: Estimation through combination of spaceborne lidar, optical imagery, and forest inventory data. Remote Sens. Environ. 2016, 173, 187-199. [CrossRef]

48. Saatchi, S.S.; Harris, N.L.; Brown, S.; Lefsky, M.; Mitchard, E.T.; Salas, W.; Zutta, B.R.; Buermann, W.; Lewis, S.L.; Hagen, S.; et al. Benchmark map of forest carbon stocks in tropical regions across three continents. Proc. Natl. Acad. Sci. USA 2011, 108, 9899-9904. [CrossRef] [PubMed]

49. Baccini, A.; Goetz, S.; Walker, W.; Laporte, N.; Sun, M.; Sulla-Menashe, D.; Hackler, J.; Beck, P.; Dubayah, R.; Friedl, M. Estimated carbon dioxide emissions from tropical deforestation improved by carbon-density maps. Nat. Clim. Chang. 2012, 2, 182-185. [CrossRef]

50. Zhang, Y.; Liang, S.; Sun, G. Forest biomass mapping of northeastern China using glas and modis data. IEEE J. Sel. Top. Appl. Earth Observ. Remote Sens. 2014, 7, 140-152. [CrossRef]

51. Zhang, G.; Ganguly, S.; Nemani, R.R.; White, M.A. Estimation of forest aboveground biomass in california using canopy height and leaf area index estimated from satellite data. Remote Sens. Environ. 2014, 151, 44-56. [CrossRef]

52. Chi, H.; Sun, G.; Huang, J.; Guo, Z.; Ni, W.; Fu, A. National forest aboveground biomass mapping from icesat/glas data and modis imagery in China. Remote Sens. 2015, 7, 5534-5564. [CrossRef] 
53. Neigh, C.S.R.; Nelson, R.F.; Ranson, K.J.; Margolis, H.A.; Montesano, P.M.; Sun, G.; Kharuk, V.; Næsset, E.; Wulder, M.A.; Andersen, H.-E. Taking stock of circumboreal forest carbon with ground measurements, airborne and spaceborne lidar. Remote Sens. Environ. 2013, 137, 274-287. [CrossRef]

54. Thurner, M.; Beer, C.; Santoro, M.; Carvalhais, N.; Wutzler, T.; Schepaschenko, D.; Shvidenko, A.; Kompter, E.; Ahrens, B.; Levick, S.R.; et al. Carbon stock and density of northern boreal and temperate forests. Glob. Ecol. Biogeogr. 2014, 23, 297-310. [CrossRef]

55. Guo, Q. Global Forest Aboveground Biomass. Available online: http://guolablidar.com/ (accessed on 1 July 2016).

56. Hijmans, R.J.; Cameron, S.E.; Parra, J.L.; Jones, P.G.; Jarvis, A. Very high resolution interpolated climate surfaces for global land areas. Int. J. Climatol. 2005, 25, 1965-1978. [CrossRef]

57. Jarvis, A.; Reuter, H.I.; Nelson, A.; Guevara, E. Hole-Filled Srtm for the Globe Version 4. Available from the CGIAR-CSI SRTM 90 m Database. 2008. Available online: http://srtm.csi.cgiar.org (accessed on 1 May 2015).

58. Carroll, M.; DiMiceli, C.; Sohlberg, R.; Townshend, J. 1 km Modis Normalized Difference Vegetation Index; University of Maryland: College Park, MA, USA, 2004.

59. Channan, S.; Collins, K.; Emanuel, W. Global Mosaics of the Standard Modis Land Cover Type Data; University of Maryland and the Pacific Northwest National Laboratory: College Park, MA, USA, 2014.

60. Friedl, M.A.; Sulla-Menashe, D.; Tan, B.; Schneider, A.; Ramankutty, N.; Sibley, A.; Huang, X. MODIS collection 5 global land cover: Algorithm refinements and characterization of new datasets. Remote Sens. Environ. 2010, 114, 168-182. [CrossRef]

61. Schutz, B.; Zwally, H.; Shuman, C.; Hancock, D.; DiMarzio, J. Overview of the icesat mission. Geophys. Res. Lett. 2005, 32, L21S01. [CrossRef]

62. Lefsky, M.A.; Keller, M.; Pang, Y. Revised method for forest canopy height estimation from geoscience laser altimeter system waveforms. J. Appl. Remote Sens. 2007, 1, 013537.

63. Lefsky, M.A. A global forest canopy height map from the moderate resolution imaging spectroradiometer and the geoscience laser altimeter system. Geophys. Res. Lett. 2010, 37, L15401. [CrossRef]

64. Su, Y.; Guo, Q.; Ma, Q.; Li, W. Srtm dem correction in vegetated mountain areas through the integration of spaceborne lidar, airborne lidar, and optical imagery. Remote Sens. 2015, 7, 11202-11225. [CrossRef]

65. Farr, T.G.; Rosen, P.A.; Caro, E.; Crippen, R.; Duren, R.; Hensley, S.; Kobrick, M.; Paller, M.; Rodriguez, E.; Roth, L.; et al. The shuttle radar topography mission. Rev. Geophys. 2007, 45. [CrossRef]

66. Rabus, B.; Eineder, M.; Roth, A.; Bamler, R. The shuttle radar topography mission-A new class of digital elevation models acquired by spaceborne radar. ISPRS J. Photogramm. Remote Sens. 2003, 57, 241-262. [CrossRef]

67. Takyu, M.; Aiba, S.-I.; Kitayama, K. Changes in biomass, productivity and decomposition along topographical gradients under different geological conditions in tropical lower montane forests on mount kinabalu, borneo. Oecologia 2003, 134, 397-404. [CrossRef] [PubMed]

68. Malhi, Y.; Wood, D.; Baker, T.R.; Wright, J.; Phillips, O.L.; Cochrane, T.; Meir, P.; Chave, J.; Almeida, S.; Arroyo, L. The regional variation of aboveground live biomass in old-growth amazonian forests. Glob. Chang. Biol. 2006, 12, 1107-1138. [CrossRef]

69. Liaw, A.; Wiener, M. Classification and regression by randomforest. $R$ News 2002, 2, 18-22.

70. Visser, H.; de Nijs, T. The map comparison kit. Environ. Model. Softw. 2006, 21, 346-358. [CrossRef]

71. Avitabile, V.; Herold, M.; Henry, M.; Schmullius, C. Mapping biomass with Remote Sensing: A comparison of methods for the case study of uganda. Carbon Balance Manag. 2011, 6, 7. [CrossRef] [PubMed]

72. Avitabile, V.; Herold, M.; Heuvelink, G.B.M.; Lewis, S.L.; Phillips, O.L.; Asner, G.P.; Armston, J.; Asthon, P.; Banin, L.F.; Bayol, N.; et al. An integrated pan-tropical biomass map using multiple reference datasets. Glob. Chang. Biol. 2016, 22, 1406-1420. [CrossRef] [PubMed]

73. Ruesch, A.; Gibbs, H.K. New IPCC Tier-1 Global Biomass Carbon Map for the Year 2000; Carbon Dioxide Information Analysis Center, Oak Ridge National Laboratory: Oak Ridge, TN, USA, 2008.

74. Margolis, H.A.; Nelson, R.F.; Montesano, P.M.; Beaudoin, A.; Sun, G.; Andersen, H.-E.; Wulder, M.A. Combining satellite lidar, airborne lidar, and ground plots to estimate the amount and distribution of aboveground biomass in the boreal forest of north america. Can. J. For. Res. 2015, 45, 838-855. [CrossRef]

75. Neigh, C.S.; Nelson, R.F.; Ranson, K.J.; Margolis, H.; Montesano, P.M.; Sun, G.; Kharuk, V.; Naesset, E.; Wulder, M.A.; Anderson, H. Lidar-Based Biomass Estimates, Boreal Forest Biome, Eurasia, 2005-2006; ORNL Distributed Active Archive Center: Oak Ridge, TN, USA, 2015. 
76. Blackard, J.A.; Finco, M.V.; Helmer, E.H.; Holden, G.R. Mapping us forest biomass using nationwide forest inventory data and moderate resolution information. Remote Sens. Environ. 2008, 112, 1658-1677. [CrossRef]

77. Saatchi, S.; Yu, Y.; Alex, F.; Nuemann, M.; Chapman, B.; Nguyen; Nemani, R.; Ganguly, S.; Zhang, G.; et al. CMS US Forest Biomass Map. 2005. Available online: http://carbon.nasa.gov/cgi-bin/cms/inv_pgp.pl? pgid $=582 \&$ format $=1$ (accessed on 1 July 2016).

78. Mitchard, E.T.A.; Feldpausch, T.R.; Brienen, R.J.W.; Gonzalez, G.; Monteagudo, A.; Baker, T.R.; Lewis, S.L.; Lloyd, J.; Quesada, C.A.; Gloor, M. Markedly divergent estimates of amazon forest carbon density from ground plots and satellites. Glob. Ecol. Biogeogr. 2014, 23, 935-946. [CrossRef] [PubMed]

79. Feldpausch, T.R.; Banin, L.; Phillips, O.L.; Baker, T.R.; Lewis, S.L.; Quesada, C.A.; Affum-Baffoe, K.; Arets, E.J.; Berry, N.J.; Bird, M. Height-diameter allometry of tropical forest trees. Biogeosciences 2011, 8, 1081-1106. [CrossRef]

80. Santoro, M.; Beer, C.; Cartus, O.; Schmullius, C.; Shvidenko, A.; McCallum, I.; Wegmüller, U.; Wiesmann, A. Retrieval of growing stock volume in boreal forest using hyper-temporal series of envisat asar scansar backscatter measurements. Remote Sens. Environ. 2011, 115, 490-507. [CrossRef]

81. Pang, Y.; Lefsky, M.; Sun, G.; Miller, M.; Li, Z. Temperate forest height estimation performance using ICESat GLAS data from different observation periods. Int. Arch. Photogram. Remote Sens. Spat. Inf. Sci. 2008, 37, 777-782.

(C) 2016 by the authors; licensee MDPI, Basel, Switzerland. This article is an open access article distributed under the terms and conditions of the Creative Commons Attribution (CC-BY) license (http://creativecommons.org/licenses/by/4.0/). 